\title{
FUNDING LIQUIDITY WITHOUT BANKS: \\ EVIDENCE FROM A SHOCK TO THE COST OF VERY SHORT-TERM DEBT
}

\author{
Felipe Restrepo \\ Lina Cardona Sosa \\ Philip E. Strahan \\ Working Paper 23179 \\ http://www.nber.org/papers/w23179 \\ NATIONAL BUREAU OF ECONOMIC RESEARCH \\ 1050 Massachusetts Avenue \\ Cambridge, MA 02138 \\ February 2017
}

The opinions in this paper represent those of the authors and do not reflect the views of the Central Bank of Colombia or the National Bureau of Economic Research. The authors thank seminar participants at the Bank of Canada, the Federal Reserve Bank of New York, the University of Pittsburgh.

NBER working papers are circulated for discussion and comment purposes. They have not been peer-reviewed or been subject to the review by the NBER Board of Directors that accompanies official NBER publications.

(C) 2017 by Felipe Restrepo, Lina Cardona Sosa, and Philip E. Strahan. All rights reserved. Short sections of text, not to exceed two paragraphs, may be quoted without explicit permission provided that full credit, including $(\odot$ notice, is given to the source. 
Funding Liquidity without Banks: Evidence from a Shock to the Cost of Very Short-Term

Debt

Felipe Restrepo, Lina Cardona Sosa, and Philip E. Strahan

NBER Working Paper No. 23179

February 2017

JEL No. G21

\section{ABSTRACT}

In 2011, Colombia instituted a tax on repayment of bank loans, thereby increasing the cost of short-term bank credit more than long-term credit. Firms responded by cutting their short-term loans for liquidity management purposes and increasing their use of cash and trade credit. In industries where trade credit is more accessible (based on U.S. Compustat firms), we find substitution into accounts payable and little effect on cash and investment. Where trade credit is less available, firms increase cash and cut investment. Thus, trade credit offers a substitute source of liquidity that can insulate some firms from bank liquidity shocks.

Felipe Restrepo

Ivey Business School at Western University

frestrepo@ivey.ca

Lina Cardona Sosa

Central Bank of Colombia

lcardoso@banrep.gov.co
Philip E. Strahan

Carroll School of Management

324B Fulton Hall

Boston College

Chestnut Hill, MA 02467

and NBER

philip.strahan@bc.edu 


\section{INTRODUCTION}

How do firms respond when bank liquidity dries up? In most economies, banks predominate as suppliers of liquidity and payments mechanisms between counter-parties. Demand deposits and credit lines (or, equivalently, very short-term loans) are fundamental payments products supplied almost uniquely by banks (Kasyhap, Rajan and Stein, 2002; Gatev and Strahan, 2009). Many firms use credit lines both to make payments and to smooth out liquidity needs over time, drawing funds when payments need to be made (i.e., making payroll or paying for supplies) and re-paying those funds when payments are received (i.e., after realizing sales receipts). Demand deposits and credit lines differ mainly in that the latter include a credit aspect (they are not pre-funded by the customer), whereas the former do not. Firms with limited access to lines of credit use deposits (out of their buffer stock of cash) to make payments, and they use trade credit with suppliers and customers to smooth payments over time. ${ }^{1}$

This paper offers a clean and well-identified setting to estimate how firms respond to a negative shock to very short-term bank loans. We show that firms substitute into cash and trade credit as alternative sources of liquidity. In industries where trade credit is less available, the increase in cash is large and leads to cuts in investment. In contrast, in industries with better access to trade credit, firms increase accounts payable but neither their cash balances nor investment change after the shock. Together, these results have two implications. First, cash is a costly substitute for bank liquidity facilities. Holding cash can be costly, both because cash

\footnotetext{
${ }^{1}$ Banks also supply term loans as a source of credit to firms, usually structuring them with a short-maturity as a key contracting tool to help solve information and monitoring problems. Outside of real estate and other projects collateralizable by hard assets, most bank loans are short term, thus requiring borrowers to roll them over frequently. This discipline in turn provides banks the option to restrict or deny credit, thereby improving borrower ex ante incentives. Diamond (1991) offers the seminal theoretical treatment of debt maturity and argues that small and information-intensive firms are often only able to borrow short-term. Stohs and Mauer (1996) provide empirical support for this prediction.
} 
yields low, after-tax returns and because cash exacerbates agency problems (Jensen (1986); Yun, (2009)). Moreover, when external funds are costlier than internal, firms needing to raise their stock of cash (because short-term bank credit has become expensive) must draw funds away from investment. ${ }^{2}$ Second, for some industries trade credit offers liquidity services that can substitute for bank-provided liquidity without distorting real decisions (investment).

The empirical setting is Colombia, whose two unique institutional features we exploit to identify how an increase in the cost of - or, equivalently, a decrease in the supply of - bank liquidity affects firms. First, in Colombia bank liquidity is more available for 'preferential clients,' those with annual sales above a specific sales cutoff set by banks, than it is for smaller firms. The large preferential firms have access to Treasury Facilities, which are very short-term extensions of credit from banks that allow firms to manage their liquidity needs. Large firms use these facilities to make payments but not to finance real investment (due to their very short maturity). Smaller firms also have access to bank credit lines for liquidity management, but these come with much more restricted access and tighter covenants. ${ }^{3}$ Second, in 2011 Colombia initiated a new law that taxed each re-payment on any bank loan. The change made shortmaturity Treasury Facilities and other very short-term debt instruments prohibitively expensive,

\footnotetext{
${ }^{2}$ Sufi (2009) argues that many firms, in fact, must self-insure against liquidity shocks because their access to credit lines is limited by low cash flow, a key contractual control mechanism that banks use to monitor their borrowers. Credit lines expose banks to substantial credit risk as well as liquidity risk because firms may want to draw funds when cash flow is low due to poor fundamentals. Cash-flow based covenants help lenders alleviate this risk, but also imply that lines do not provide firms insurance against low cash flow in bad states. In fact, Lins et al (2010) survey CFOs from the largest firms across 29 countries and conclude that credit lines are a more important source of liquidity than cash among their sampled firms, but also that firms will simultaneously hold cash buffers to self-insure against bad states. Thus, credit lines are often used to allow firms to take advantage of future uncertain investment opportunities.

${ }^{3}$ Small firms can also access short-term debt (say a 30-day loan), but supply is more constrained and conditions (rates, collateral, covenant) less favorable. Operationally, firms with sales below the sales threshold would bank out of a branch office; in contrast, firms with higher sales are assigned to a loan officer/account manager who gives this customer preferential treatment.
} 
but had little effect on the cost of long-term bank loans (due to the very low rate of $0.4 \%$ ). Since the tax shock had a much greater effects on large firms (i.e. those with more access to very short term debt), we identify the causal effect of shocks to bank-supplied liquidity from the shift in the relationship between firm size and short-term bank debt for firms above the sales cutoff. The identification strategy, a modified regression-kink design (RKD), works like a heterogeneous treatment effects model.

We report three core results. First, there is a strong 'first stage' relationship between large-firms' use of short-term bank credit and the tax shock. In other words, the use of shortterm bank borrowing for liquidity among large firms falls sharply after the 2011 tax shock; in contrast, there is very little change among small firms. Second, the decline leads to an increase in both trade credit and cash. Accounts receivable and accounts payable increase after 2011, with the increase being larger for firms more exposed to the tax shock. The result suggests substitution between these two payments technologies: trade credit and cash. As we discuss below, trade credit offers a payments mechanism for firms that can avoid the punitive tax regime discouraging the use of bank credit lines.

Third, we test for real effects. The decline in bank liquidity has a small effect on real investment that is not statistically robust (and the decline has no effect on profits). But this effect varies by industry. For firms in industry segments where trade credit is relatively available, we find a large substitution into trade credit and no investment response. Moreover, the substitution to trade credit seems complete, as there is no change in cash for firms in these sectors. Firms in industries with greater frictions in the supply of trade credit, however, experience both a large increase in cash and a decline in investment (but no change in trade credit). Thus, in these 
segments the decline in bank liquidity spills over to real decisions because firms need to increase their buffer stock of cash to manage liquidity. The increase displaces investment.

In contrast to the extant literature, our shock - discussed in detail in Section II - focuses very precisely on banks’ role as liquidity providers. Most existing studies test how shocks that affect banks’ cost of funds (e.g. monetary policy), or bank solvency (e.g. bank failures, as in Peek and Rosengren, 2000), or the supply to banks of local deposits (e.g. Becker, 2007; Gilje et al, 2016) propagate to non-financial firms. These kinds of shocks affect both the liquidity/payments role of banks and the credit-production role, thus making it hard to unpack which aspect of banking (credit or liquidity) is affecting which outcomes for firms. We know of no existing study that can isolate a shock to the payments/liquidity role alone. As we explain in detail below, the tax shock in our setting increases the cost of short-term bank credit substantially, but it has little effect on the cost of longer-term bank credit. We find that trade credit can substitute for the liquidity-provision role of banks in some industries, consistent with Fisman and Love (2003), who show that poor financial development constrains growth less in industries that can substitute toward trade credit. Our setting differs because we have an exogenous shock to bank liquidity supply within a well-developed (bank-based) financial system. ${ }^{4}$

Our results on investment suggest that most of the documented real effects from bank shocks occur because of disturbances to their credit role, even though many shocks themselves originate from liquidity problems. As we have argued, most of this literature considers cases

\footnotetext{
${ }^{4}$ Most existing studies of banks as liquidity suppliers focus on why banks combine deposits with credit lines (e.g. Kashyap, et al, 2002; Gatev and Strahan, 2006; Gatev, Schuerman and Strahan, 2009) and how lines are used, but do not explore substitution into trade credit, as we do. See also Jimenez, Lopez and Suarez, 2009, Ivashina and Scharfstein, 2010, Campello, et al, 2013. For a survey on the use of bank credit line by non-financial firms to manage liquidity, see Demiroglu and James (2011).
} 
where drawing a bright line between credit and liquidity is difficult. The 2007-2008 Financial Crisis illustrates on a grand scale how difficult such a separation can be, as solvency shocks metastasized when amplified by illiquidity, leading to a massive reduction in both bank credit and liquidity, followed by an economic disaster (e.g., Brunnermeier, 2009; Ivashina and Scharfstein, 2010). Much of the banking and macroeconomics literature has focused on the importance of banks as suppliers of both liquidity and credit to firms, but without a way to separate the two roles. ${ }^{5}$ To take a specific example of how hard that separation can be, consider Merrouche and Nier (2010), who study a shock that improves bank payments systems. The paper finds that following payments innovations (in several Eastern European countries), funds flowed into banks, which in turn used those funds to expand credit. Our empirical setting is again different because it allows us to focus on the liquidity role alone, with little feedback to the credit role of banks. ${ }^{6}$ We find that many firms can attain this liquidity via firm-to-firm trade credit without constraining their operating decisions.

We also contribute to the literature on trade credit by cleanly tracing out how firms respond to a well-identified increase in trade credit demand originating from a shock to their banks. Early studies, such as Petersen and Rajan (1997), rely on reduced form links from firm characteristics to accounts payable and receivable, making it hard to sort out demand v. supply side effects. More recent papers, in contrast, attempt to identify one side or the other. Amberg et al. (2016), for example, use the failure of Panaxia - a Swedish cash-in-transit firm - as a plausibly exogenous shock to liquidity demand for firms exposed to the failure. They find that

\footnotetext{
${ }^{5}$ In fact, Rajan (1998) describes how those two roles jointly evolved in medieval European banking, whereby money changers began using their 'float' from customers needing payments services to provide credit to other customers. This history illustrates the tight link between the liquidity and credit roles of banks.

${ }^{6}$ In fact, there is no change in aggregate deposits in the Colombian banking system after 2011.
} 
this shock leads to increases in the use of trade credit and declines in firms' cash balances. Using shocks to payment terms in the French trucking industry, Barrot (2016) finds that firms substitute into cash when trade credit supply declines. Breza and Lieberman (2016), using a similar restriction on trade credit terms among Chilean retailers, also find a decline in trade credit accompanied by an increase in vertical integration.

A number of existing studies emphasize the relative substitutability of banks v. trade creditors. Both Wilner (2000) and Cunat (2007) argue that trade creditors have advantages over banks in enforcement and in renegotiation. Burkart and Ellingsen (2004) argue that trade creditors have an advantage over banks because they directly supply goods rather than cash, which unlike goods is uniquely vulnerable to diversion (i.e. theft). But none of these studies trace out how shocks to banks affect trade credit, as we do. Similar to our study, GarciaAppendini and Montoriol-Garriga (2013) find indirect evidence of substitution, in that firms with relatively high cash extend more trade credit and constrained firms use more trade credit during the financial crisis. The interpretation is complicated, however, because high-cash firms also were better able to sustain investment after the crisis (Duchin, Ozbas and Sensoy, 2010), and because the crisis affected both bank liquidity and credit supply as well as investment demand. Our study differs in that we examine a specific decline in bank-supplied liquidity from the tax shock, as opposed to a broad credit shock like the crisis, with limited spillovers to potential confounds such as changing investment opportunities.

In the next section, we describe the specifics of our institutional setting. Section III outlines the research design and identification, the data, and the results. We conclude briefly in Section IV. 


\section{COLOMBIAN BAD TAXES, THE 2011 CHANGE, AND TAX AVOIDANCE}

For several reasons, Colombia offers an interesting setting to assess the importance of bank loans for firm liquidity management. First, the 2011 tax change that we describe below offers a clean shock to the cost of using bank credit for liquidity purposes. Second, Colombia is a bank-centric economy with limited alternatives for liquidity in other parts of the financial system, such as what the commercial paper market would offer to large, public firms in the U.S. Third, we have access to detailed financial statements data on a large, representative sample of firms in Colombia, both before and after the tax shock, which allows us to observe within-firm changes in cash management, financial policies, investment and profits.

The 2011 tax shock emerged out of the bank account debit tax (BAD), adopted in Colombia in 1999 amid a weak economy, an unhealthy financial system, and low fiscal revenues. ${ }^{7}$ Under the original legislation, all debits from bank accounts generate a tax liability. That is, BAD taxes affected withdrawals from bank accounts, including check clearances, electronic transfers, ATM cash withdrawals, loan payments (but, until 2011, firms could evade the tax on loan re-payments) and most other transactions that involve debiting money from a bank account. $^{8}$

The tax rate started at $0.2 \%$ per transaction and increased to $0.3 \%$ in 2001 . The rate increased again in 2004, to its current level of 0.4\%. Over time, firms and households found ways to avoid the tax. For example, payments made outside the banking system do not pay the

\footnotetext{
${ }^{7}$ Other countries have implemented similar taxes on bank transactions (e.g. Australia, Argentina, Brazil, Ecuador, Hungary, Peru and Venezuela). In the U.S., a two cent tax on bank checks was imposed during the Spanish-American war at the end of the nineteenth century, and then from June 1932 through December 1934. Lastrapes and Selgin (1997) document how the Hoover administration adopted the tax in the early 1930s when "faced with a dramatic collapse in income tax revenues."

${ }^{8}$ Prior to 2011 firms could use funds held in investment accounts (e.g. a money market fund) to dispense the loan principal payment to the bank without incurring the tax. The 2011 law change eliminated the ability to use this mechanism to avoid the tax on loan payments.
} 
BAD tax. Figure 1 shows the general effect of the advent of tax arbitrage by plotting BAD tax receipts (relative to GDP) over time. As economic agents learn how to avoid the tax, collections gradually decline. In fact, Arbeláez et al. (2002) document a significant increase in the use of currency relative to bank deposits following the introduction of the tax, which is the easiest way to avoid it. They also show a decrease in the number of checks cleared after the tax, and checks would often circulate for many payments and with multiple endorsements before finally clearing (and thus being taxed). Restrepo (2016) shows that this dis-intermediation in the Colombian economy after 1999 reduced bank credit production, which in turn harmed financially dependent firms. Thus, as with most of the current banking literature, the original BAD tax affected both the liquidity and credit roles of banks.

Prior to 2011, large firms could - and did - use Treasury Facilities (essentially very short-term bank loans) to make payments without incurring the BAD tax. Payors would borrow funds and deposit those funds directly into the recipient's bank account, thereby avoiding a bank account withdrawal and thus any tax. When the loan was due, firms would dispense the loan payment using an investment account, also avoiding paying the tax on the repayment. The 2011 law stopped this practice. ${ }^{9}$ As can be seen in Figure 1, the change worked, as BAD tax receipts jumped by about 1/3 after the law change (from 0.59\% to 0.82\% of GDP in 2010 and 2011 respectively) without the need to increase the statutory tax rate, which has remained at $0.4 \%$ since 2004.

The easiest way to understand the effect of the tax change is with an example. Consider a firm purchasing \$10 million in supplies. Payment options include: 1) an immediate cash

\footnotetext{
${ }^{9}$ Law 1430 of December $29^{\text {th }}, 2010$.
} 
disbursement from funds withdrawn from the firm's checking account; 2) the use of trade credit (with, say, up to 30 days to pay); or, 3) the use of funds borrowed from a Treasury Facility. Under the tax regime prior to 2011 , the firm would pay a tax of $\$ 40,000$ (0.4\% times $\$ 10$ million) using either cash or trade credit because either mechanism would require a debit of $\$ 10$ million from the firm's checking account. The difference between the two comes down to timing: with cash, payment would be immediate; with trade credit, a firm could make the payment any time over the subsequent 30 days. The second option - trade credit - would allow the firm to time its payment to coincide with its sales receipts, thus lowering the optimal balance in its checking account. ${ }^{10}$ Note that the tax burden depends on the flow of payments through the checking account, not the level (or buffer stock) held in the account itself. The firm, however, could avoid the tax entirely before 2011 by borrowing the $\$ 10$ million from a Treasury Facility and having the payment deposited directly into the supplier's bank. Firms with access to these facilities would choose them to avoid the transaction tax.

In 2011, the Colombian Government eliminated the third option to use funds borrowed from a bank, such as a Treasury Facility, to avoid the BAD tax. This change occurred both because banks could no longer put borrowed funds directly into a third-party's account, and because borrowers would incur the tax when those funds were later re-paid to the bank. Thus, after 2011 borrowing \$10 million from the bank for a payment would incur two taxes because these funds first would go into the borrower's checking account (and hence incur the BAD tax when the supplier gets paid), and a second time when the loan comes due. Given the change, firms are now better off either paying suppliers immediately from cash (i.e. from their checking account), or using trade credit. Both would incur a one-time tax payment because the firm would

\footnotetext{
${ }^{10}$ Trade credit has costs as well, which we are leaving out for illustrative purposes.
} 
have to debit the same \$10 million from its account to pay the supplier eventually, thereby incurring the same $\$ 40,000$ tax (ignoring the small effect of time-value of funds). However, trade credit would have the advantage of allowing the firm to time its payments to coincide with incoming sales receipts. Thus, we would expect that firm demand for trade credit would increase after 2011 to improve its ability to smooth payments and conserve on its holdings of a cash buffer stock (i.e. accounts payable would rise). Market clearing dictates that the increase in trade credit demand generates and equivalent increase in trade credit supplied, so accounts receivable also should increase.

As we will show, the tax law change in 2011 encouraged firms to switch away from bank loans for payments and to increase the use of trade credit (or, if not available, cash). However, as we have argued, the change had little effect on the cost of long-term credit from banks. The tax change also had no effect on the other side of the banking system's balance sheet (hence there is no reason to expect the supply of longer-term loans to change); nor did it have a large effect on the cost of using bank debt to finance investment directly.

Figure 2 illustrates this latter point. We graph the increase in borrowing cost on an annualized basis as a function of a loan's maturity. Since borrowers must pay the $0.4 \%$ tax for every loan re-payment, it affects the ‘all-in’ cost of debt most for very short maturity loans. For instance, consider the annualized cost for an 8\% (APR) loan, roughly the average rate for a bank loan in Colombia. At a maturity of five days, the all-in cost annualizes to $37.25 \%$ (= [( $1+8.0 \%$ $\times 5 / 365) \times(1+0.4 \%)-1] \times(365 / 5))$; in contrast, the 'all-in' cost for a 1-year loan comes to just $8.4 \%(=[(1+8.0 \% \times 365 / 365) *(1+0.4 \%)-1] \times(365 / 365))$. By the time maturity gets beyond 60 days, the effect of the tax is small (Figure 2). At maturity of one year, the tax falls to just $0.4 \%$, a five percent increase in the average interest rate on a bank loan in Colombia; for longer 
loans the effect is even smaller. And, the tax clearly had a major impact on the use of bank liquidity. Aggregate issuance of bank loans for liquidity management to preferential customers Treasury Facilities - falls nearly to zero at exactly the time that the tax goes into effect (Figure

3).

\section{RESEARCh DESIGN, DATA AND RESUltS}

\section{Research Design \& Identification}

As explained above, we exploit two unique features of the Colombian financial system.

First, firms with sales above a size threshold of COP 15,000 million have access to Treasury Facilities, which expands their access to short-term bank loans for payments uses. ${ }^{11}$ Smaller firms do sometimes use bank credit lines to make payments, but these are more limited in the amount committed and come with tighter contractual restrictions (e.g., covenants) compared to the Treasury Facilities. Thus, small firms self-insure by holding higher cash stocks (i.e. bank deposits) as a store of liquidity to make payments. Second, the tax change in 2011 substantially raised the cost to large firms of using the Treasury Facilities because their maturity is typically very short (normally under one month). Use would generate a BAD tax liability because the tax comes due when funds get repaid. The 2011 tax change thus should have reduced the use of bank liquidity both from credit lines and Treasury Facilities, and that effect should increase with firm size for firms above the sales cutoff (because only large firms had access to Treasury

\footnotetext{
${ }^{11}$ Different banks have used different sales thresholds to classify firms into 'small and medium enterprises' and 'corporate' clients. For the top five banks in Colombia: Bancolombia, Banco de Bogota, Davivienda, Banco de Occidente and Banco Polular, the threshold in 2010 ranged between COP 15,000 million for both Bancolombia and Banco de Occidente, to COP 20,000 for Banco de Bogota and Davivienda. Since firms above COP 15,000 could access the portfolio of 'corporate' financial products from at least one bank, we use the lower bound of the range as our threshold. Together the top five banks in Colombia account for over $60 \%$ of total assets in the banking system. The annual sales threshold of COP 15,000 million is approximately equivalent to \$5 million.
} 
Facilities). This effect can be seen clearly in the left panels of Figure 4, where we plot the annual flow of bank loans with maturity under 60 days (per dollar of assets) against firm sales (Figure 4A) and against log of firm sales (Figure 4B) from 2008 to $2010 .^{12}$ For firms below the sales cutoff, the annual issuance of these short-term loans is just $1.6 \%$ of assets, versus $5.2 \%$ for firms above the cutoff. Above the size threshold, short-term debt increases with sales (and log sales) because access to Treasury Facilities improves with firm size.

We aim to identify the causal effect of a negative shock to short-term bank debt for liquidity on firm financial and real decisions. One might be tempted to use the kink illustrated in Figure 4 to generate identification from the slope change around the sales-size threshold, as in a standard Regression Kink Design (RKD). This strategy works well in settings in which kinks emerge exogenously. For example, Card et al. (2012) exploit policy rules in unemploymentinsurance programs in which the source of the slope-change comes from non-linearities in benefits formulas. ${ }^{13}$ In our setting, we would need to assume that the slope steepens around the kink only because liquidity-supply constraints loosen with size. But firm liquidity depends also on demand. What if part of the variation above the cutoff represents larger firms' greater demand for liquidity, compared to that of smaller ones? To avoid making strong assumptions about liquidity demand, we exploit the 2011 tax. The change made short-maturity Treasury Facilities prohibitively expensive, as a borrower would incur the tax each time it repaid the amount borrowed. In fact, the aggregate issuance of Treasury Facilities declines by a staggering 73\% right after the tax law was introduced (recall Figure 3). Since large firms have increased

\footnotetext{
12 Our data do not allow us to separate out Treasury Facilities from other loans at the firm level; hence, we use loans with maturity under 60 days as a close proxy for them.

${ }^{13}$ In another context, Scharlemann and Shore (2016) use kinks in the rules for principal reduction under the Home Affordable Modification Program (HAMP's) to infer the causal effect of debt forgiveness on default.
} 
access to these credit facilities, the 2011 tax change mattered most to firms above the sales threshold, and its impact increased with sales size thereafter. Thus, firms above the threshold should have reduced their use of Treasury Facilities for liquidity purposes, and the decrease should have increased with size. Comparing the left and right panels of Figure 4 illustrates this pattern exactly, as the relationship between sales and short-term loans flattens beyond the kink after 2011.

We exploit these two unique features - represented in Figures 3 and 4 - to build an excludable instrument based strictly on the slope change above the sales-size threshold due to the 2011 tax law. The instrument equals a triple interaction between firm (log) sales, an indicator equal to one for firms above the cutoff before the tax change (reflecting the increased slope above the cutoff), and an indicator equal to one after the 2011 tax change (reflecting the slope’s flattening). The flattening reflects the increasing cost of using Treasury Facilities and other very short-term bank debt due to the tax in the post-2011 period. Our identification strategy requires that the flattening reflect only the tax change (as opposed to some other change related to firm size that might reflect liquidity demand). If true, then our instrument passes the exclusion restriction. As usual, the exclusion restriction is not directly testable. But we do show no changes in the sales/short-term bank loan link prior to 2011. This test acts like a test for parallel trends that has become standard when researchers use difference-in-differences methods (Roberts and Whited, 2012).

Given these features, we estimate a first-stage equation with the following general structure: 


$$
\begin{gathered}
\text { STD }_{i, t}=\alpha_{i}+ \\
\gamma_{t}+\beta_{1} \text { LnSales }_{i} \times \text { AboveCutoff }_{i} \times \text { Post }_{t}+\beta_{2} \text { AboveCutoff }_{i} \times \text { Post }_{t} \\
+\beta_{3} \text { LnSales }_{i} \times \text { Post }_{t}+\text { Other Controls }_{i . t}+\varepsilon_{i, t}
\end{gathered}
$$

where $S T D_{i, t}$ equals the flow of loans with maturity under 60 days used during the year, divided by total assets at the beginning of the year. ${ }^{14}$

We include both firm $\left(\alpha_{i}\right)$ and time $\left(\gamma_{t}\right)$ fixed effects in all models to control for unobserved heterogeneity across firms as well as macro-economic shocks affecting all firms.

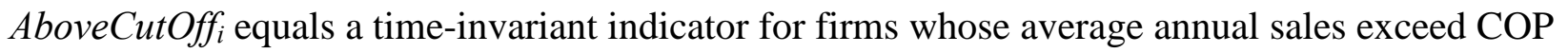
15,000 million in the pre-2011 years, which gives them access to Treasury Facilities. LnSales $i$ equals firm sales size (again, time invariant using the pre-2011 period). The direct effects of each of these variables, as well as their interactions, get absorbed by the firm fixed effects. By using pre-2011 levels, we avoid a potential feedback from the tax change to firm outcomes. We also allow the effects of both LnSales $_{i}$ and AboveCutOff $i$ to change after 2011 by interacting each with $\operatorname{Post}_{t}$ (= an indicator for all years after 2011). The time effects absorb the direct effect of Post.

We argue that the shift in the slope in the relationship between $\operatorname{LnSales}_{i}$ and $S T D_{i}$ (captured by $\beta_{1}$ in equation (1)) occurs because of the tax-law change in 2011. Moreover, this change plausibly affects other aspects of firm financial and operating policies only through reduced use of bank liquidity. Hence, the triple interaction term is an excludable instrument. To test whether higher costs of short-term debt, in turn, induce other changes in firm behavior, we estimate the following reduced form models:

\footnotetext{
${ }^{14}$ We are not able to observe exactly the Treasury Facilities in our firm-level data, nor are we able to observe flows into and out of credit lines. Hence, we use issuance of very short-term bank loans as a proxy for bank liquidity.
} 


$$
\begin{aligned}
Y_{i, t}=\alpha_{i}+\gamma_{t} & +\beta_{1} \text { LnSales }_{i} \times \text { AboveCutoff }_{i} \times \text { Post }_{t}+\beta_{2} \text { AboveCutoff }_{i} \\
& \times \text { Post }_{t}+\beta_{3} \text { LnSales }_{i} \times \text { Post }_{t}+\text { Other Controls }_{i . t}+\varepsilon_{i, t}
\end{aligned}
$$

Where $Y_{i, \mathrm{t}}$ represents other outcomes related to financial policies (leverage, cash and trade credit) or operating policies $($ investment $=$ capital expenditures $/$ assets, and profit margin = earnings $/$ sales). Assuming the exclusion restriction holds, the coefficient on the triple interaction ( $\beta_{1}$ in equation (2)) reflects the causal effect of declines in short-term debt on these outcomes. ${ }^{15}$

Another way to understand our empirical strategy is as an application of a 'natural experiment' research design, where the treatment comes from the 2011 tax-law change. Firms below the size cutoff act as a pure 'control' sample, in that they are not affected at all by the tax due to their inability to access Treasury Facilities, either before or after treatment. Large firms constitute the treatment group, and we exploit heterogeneity in exposure to the treatment by interacting size for firms above the cutoff with the post-treatment indicator.

We report our results with three approaches. First, we report them only with firm and time fixed effects. Second, we add six additional control variables to the right-hand side. These include the following time-varying firm characteristics: 1) asset growth; 2 ) size (= log of firm assets); 3) asset tangibility (= property, plant and equipment / assets); 4) asset turnover (= sales / assets); 5) log of firm age; and 6) the interaction between lagged GDP growth and LnSales . We $^{\text {. W }}$ measure each control as of the prior year to ensure that they are predetermined relative to the outcome. Third, we replace the time effects with industry $\times$ time effects, where we define industry by ISIC at the section level. This level of granularity generates 13 industry classifications (see Appendix Table IA.2). The industry-time effects help control for industry-

\footnotetext{
15 There is an equivalent representation of equation (2) as a second-stage of a 2SLS regression (since the model is just-identified). We report just the reduced forms to streamline the exposition.
} 
specific common shocks that might drive financial or operating decisions, such as investment opportunities. To build standard errors, we cluster by firm.

Data

Our firm-level sample comes from financial statements data collected by Colombia's Corporations Superintendence (Superintendencia de Sociedades), a government agency in charge of overseeing privately held corporations. ${ }^{16}$ We also obtain loan issuance for each firm from Colombia's central bank (Banco de la República). The sample includes annual firm-level data between 2008 and 2013. Focusing on this period allows us to examine firm behavior for three years before (2008-2010) and three years after (2011-2013) the tax law change. We drop utilities (ISIC codes 40 and 41) and financial firms (ISIC codes 65 to 67) from the sample. The final sample contains 67,212 firm-year observations corresponding to 12,649 distinct firms between 2008 and $2013 .{ }^{17}$

Table 1 reports summary statistics for our data, divided into two groups: firms with and firms without access to Treasury Facilities. As expected, firms with access are larger (true by construction). They also have more credit across all dimensions than smaller firms: more short and long-term bank debt as well as more trade credit (both accounts receivable and payable). Conversely, large firms hold less cash than smaller ones. These differences are as expected, but it is worth re-emphasizing that our identification does not rely on comparing these two sets of firms. Instead, we rely on the differential impact of the 2011 tax change across firms within the

\footnotetext{
${ }^{16}$ Privately held companies represent the vast majority of firms in Colombia. In 2010, for instance, there were only 92 listed firms in Colombia's stock exchange (Bolsa de Valores de Colombia). In contrast, we have data for over twelve thousand private firms in that same year. Public firms are not part of our dataset.

${ }^{17}$ The data are free from survivorship bias (records are not deleted). If a firm no longer meets the conditions set by law requiring submission of financial statements, its data time series ends but its historical data remain.
} 
larger group. Other dimensions - such as investment rates, profit margins and asset growth differ much less across the two groups.

\section{Results: First-stage Effects of Tax Change on Bank-Supplied Liquidity}

Table 2 reports our first-stage regression (Equation 1). We find a very strong effect of the tax law change on the link (slope) between firm sales and short-term bank debt (STD) for firms above the sales-size threshold (COP 15,000 million). We report the estimates both with and without control variables (columns $1 \& 2$ ), and then we introduce industry $\times$ time effects (column 3). We also report the models with a 'placebo' test that allows the relationship between Log Sales and STD to flatten in 2010, one year prior to the actual change in tax rules (columns 46). These latter tests are analogous to 'parallel trends' tests used in difference-in-differences models, in that we are checking that the change in slope (the basis of our identification) stems from the 2011 tax change, rather than from some other change that happens to occur around the same time.

Across all six models, the relationship between firm sales and STD flattens after 2011. We focus on this flattening for firms with the greatest access to banks as liquidity suppliers those preferential clients who can issue Treasury Facilities to make payments. As we have explained, this mechanism becomes prohibitively expensive after 2011; hence, there is a big decline in STD among large firms. Essentially, these regressions replicate the graphical evidence in Figure $3 .{ }^{18}$ The magnitude is large: firms that are one log-point above the sales threshold (for access to the Treasury Facilities) reduce their use of STD by 1.2-1.3\% more than firms that are at

\footnotetext{
${ }^{18}$ In Table IA.3 in the Internet Appendix, we show that the flattening happens for loan issuance below 30 days and between 30 and 60 days, but not for issuance of longer-term loans.
} 
the threshold. The difference equals about one-third of the mean issuance of STD by firms above the cutoff (= 0.039; see Table 1$)$.

We use this shift in slope to identify whether the exogenous change in usage of STD has a causal effect on other firm financial and operating policies. In other words, we use LnSales $_{i} \times$ AboveCutoff $_{i} \times$ Post $_{t}$ as the identifying instrument in Equation (2). The exclusion restriction is plausible as long as STD changes only because of the 2011 tax-law change; since this tax had no effect on other firm decisions, financial and operating policies should only change because of the effects of STD on them. This assumption, while not directly testable, is supported by the results in columns 3-6, as there is no significant flattening before 2011 (i.e. we pass the equivalent of a 'parallel trends' test). ${ }^{19}$

\section{Results: Financing Effects}

Tables 3 and 4 link the tax shock to firm financial policies: leverage $=$ bank debt $/$ assets (as well as its subcomponents, short-term bank debt/assets and long-term bank debt/assets), cash / assets, and trade credit (accounts payable / assets and accounts receivable / assets). We report each set of models with three specifications, as in Table 2. Table 3, Panel A reports results for leverage and cash; Table 3, Panel B then dis-aggregates leverage by maturity (over v. under oneyear in residual maturity). Table 4 reports results for trade credit.

Three dimensions of financial policy change when firms cut STD for liquidity management. First, firms borrow less from banks overall. In the leverage regressions, the

\footnotetext{
${ }^{19}$ We have estimated an expanded placebo test in which the slope of the relationship between LnSales and STD can differ in each year. These models support the idea that the slope is flatter in all years after the tax shock, and in no years before the tax shock (see table IA.4 in the Internet Appendix). We also have estimated similar placebo regressions for the other outcomes and find similar (non) results. That is, we pass this placebo test in reduced form analysis of operating and financial outcomes.
} 
coefficient on the triple interaction - LnSales $_{i} \times$ AboveCutof $_{i} \times$ Post $_{t}$ - enters negatively and significantly (Table 3, columns 1-3). Firms that are one log-point above the cutoff cut leverage by about $1 \%$ of assets more than firms at the cutoff, which is important relative to mean leverage of $19 \%$ for these firms (Table 1). Second, firms hold more cash after the tax change (columns 46). The relative increase in cash for more-exposed firms represents about $10 \%$ of mean cash balances for large firms. The change in the stock of cash occurs, we surmise, because firms are more likely to use direct cash disbursement to make payments after the tax change as a substitute for payments from Treasury Facilities or lines of credit (although we cannot directly measure these flows of payments).

Panel B of Table 3 shows that all of the declines in leverage come at the short-end of the maturity spectrum. We find no change in long-term bank debt/assets. This 'non-result', along with the placebo evidence, supports our identification assumption: the tax shock has a very large effect only at the short-end of the maturity distribution (recall Figure 2). It also suggests that long-term bank debt is not a close substitute for short-term debt; otherwise, firms would increase their use of long-term debt. The two serve different roles in corporate finance. Short-term bank loans exist to help firms manage payments and liquidity; long-term debt exists to help firms finance long-term investment projects.

Third, the tax change has a substantial effect on trade credit. Both accounts payable and accounts receivable increase following the tax change (Table 4). Accounts payable increase by 0.006 to 0.01 more for exposed relative to less-exposed firms (columns 1-3), whereas accounts receivable increase somewhat less. The relative increase in accounts payable for more exposed firms represents about a $5 \%$ increase over the unconditional mean $(=0.15$; recall Table 1$)$. Notably, the increase in accounts payable is larger in magnitude than the increases in accounts 
payable. $^{20}$ This may reflect the fact that the tax shock itself raises the cost to firms of supplying trade credit to their counterparties. Hence, the tax shock induces both an increase in demand for trade credit and a decline in its supply. The observed increase in the equilibrium quantity of trade credit implies a strong effect of the reduction in short-term bank credit on demand for liquidity via trade credit. (These changes also suggest an increase in the equilibrium price of trade credit, which we explore below.)

\section{Results: Operating (or Real) Effects}

Table 5 reports how investment (= capital expenditures/assets) and firm profit margins (= earnings/sales) are affected by changes in the tax cost of using bank liquidity. We again report both outcomes with and without other control variables (six columns).

Overall, real effects are small and generally not statistically robust. Investment declines somewhat, but only in the models with control variables. This weak result stands in contrast to much of the banking literature, which consistently finds that constraints on banking due to adverse shocks lead to declines in real outcomes for non-financial firms. But, as we have argued, our setting differs from much of that literature because our shock only affects the cost of using very short-term borrowing from banks. Unlike, say, a shock to monetary policy, ours is a pure liquidity-management shock that does not feedback to credit supply. Thus, almost all of the

\footnotetext{
${ }^{20}$ Across the whole economy, the sum of accounts payable and receivable must be equal, but our effects are somewhat larger for payables than for receivables. This occurs for at least two reasons. First, we scale our outcomes: the same $\$ 1$ million in receivables for the lending firm equates to the \$1 million in payables for the borrowing firm; however, the two do not equate once expressed as a ratio if the scaling variable - assets in our case - is not exactly the same for both firms. Second, our regressions only capture payables to and receivables from customers who are other firms. We do not capture the large segment of receivables to households purchasing goods and services from firms to nonfirm payees, such as employees, or from and to firms outside the country (i.e. exports and imports).
} 
effect of the shock gets absorbed by firms' substituting into other means of payments immediate repayment with cash and deferred repayment with trade credit.

\section{Results: Focusing on the role of Trade Credit}

We have shown that trade credit usage rises sharply with the tax change, but real effects change less. Thus, it seems that trade credit allows firms to mitigate the impact of the tax shock to bank liquidity. But do firms less able to substitute trade credit for bank credit experience real operating effects when the tax law changes? To see why they might, imagine a firm that can wait just 30 days to make its payments (without penalty), but waits 45 days to receive cash from customers after a sale. A firm like this needs a bridge to span the 15-day timing mismatch. The bridge could be built either by holding a cash buffer stock or by borrowing on a credit line or Treasury Facility. Clearly if the option to access bank credit over very short horizons like 15 days becomes more expensive, this firm would need to increase its cash, which in turn may displace investment, either because internal funds get diverted away from investment, or because holding a higher buffer of cash leads to permanently lower investment. Firms in the opposite situation, those with greater access to trade credit, would be less dependent on banks (or cash) for liquidity because of their ability to substitute into trade credit.

Given this intuition, we follow Murfin and Njoroge (2015) and construct a measure of trade credit access to firms that reflects the timing of payments flows in and out of the firm. Specifically, we build an indicator, High TC Access, equal to one for firms in industries in which the average days to make payments (= accounts payable / (cost of goods sold + change in inventory)) exceeds the average days to receive payments (= accounts receivable/sales). Firms that can wait longer to make payments (relative to when they receive them) are in a better position to substitute trade credit for bank-supplied short-term loans. 
Much of the theory of trade credit relies on the idea that suppliers have an informational advantage over other providers of liquidity (i.e., banks), or that suppliers are best able to redeploy collateral. Schwartz (1974) provides an early explanation of trade credit as a key component of a firm's pricing policy, in part motivated by differential access to capital markets. Smith (1987) provides a broad theory of inter-firm credit that includes product quality, market power and sunk costs. She proposes that delayed payment facilitates allow buyers to verify product quality before paying. Smith also models trade credit as a screening contract where terms can be designed to provide credit quality information, as the response to credit terms may help identify low creditworthiness buyers. Burkhart and Ellingsen (2004) argue that a key advantage for trade credit suppliers is their certainty that the transaction with the buyer has occurred. Overall, such explanations suggest that industry characteristics will determine the availability of trade credit. In fact, Ng, Smith and Smith (1999) use data compiled from a survey to credit managers for over 2,000 Compustat firms and show that there is significant variation in trade credit policies across industries, while there is little variation within industries.

Petersen and Rajan (1997) provide comprehensive empirical evidence correlating accounts payable and accounts receivable to firm characteristics using small US firms. They show that the use of accounts payable is more than $70 \%$ lower for firms whose inventories are finished goods, compared to firms with no finished goods in inventory. Fisman and Love (2004) report that they find similar correlations based on comparisons across countries and industries. In contrast, Giannetti et al. (2011) find more trade credit supplied by firms selling differentiated products. The difficulty with these reduced-form correlations, however, is that they reflect both supply and demand-side factors. On the trade credit supply side, raw materials are easier to repossess and put into alternative uses. On the demand side, however, trade credit users may 
have a greater demand to delay payments on differentiated goods in order to certify their quality (Smith, 1987).

Our setting allows us to identify a shock to trade credit demand stemming from the tax on short-term bank credit. Thus, firms that face a better availability trade credit (i.e., higher supply elasticity) ought to substitute more into accounts payable in response to the negative tax shock, compared to firms with less availability. To test this idea, we measure trade credit availability in a setting that has not been distorted either by the BAD taxes or by the tax change on bank loans from 2011; that is, we construct our indictor based on the median Compustat firm in the United States by industry, defined at the 3-digit ISIC level. ${ }^{21}$ Murfin and Njoroge (2015) document substantial heterogeneity in this measure by firm size, but our purpose is to avoid variation in access due to firm-specific characteristics and to capture the overall availability of trade credit based on exogenous industry characteristics such as the nature of inventories (raw materials v. finished goods) or technology differences.

We focus in this analysis on the reduced form regressions (equation (2)) with additional interaction terms. These modified reduced forms, with trade credit interactions, are as follows:

$$
\begin{aligned}
& Y_{i, t}=\alpha_{i}+\gamma_{t}+\beta_{1}\left(\text { LnSales }_{i} \times \text { AboveCutoff }_{i} \times \text { Post }_{t}\right)+\beta_{2}\left(\text { AboveCutoff }_{i} \times \text { Post }_{t}\right) \\
& +\beta_{3}\left(\text { LnSales }_{i} \times \text { Post }_{t}\right) \\
& +\beta_{4}\left(\text { LnSales }_{i} \times \text { AboveCutoff }_{i} \times \text { Post }_{t} \times{\text { High TC } \left.\text { Access }_{k}\right)}\right. \\
& +\beta_{5}\left(\text { AboveCutoff }_{i} \times \text { Post }_{t} \times \text { High TC Access }_{k}\right) \\
& +\beta_{6}\left(\text { LnSales }_{i} \times \text { Post }_{t} \times \text { High TC Access }_{k}\right)+\text { Other Controls }_{i . t}+\varepsilon_{i, t}
\end{aligned}
$$

\footnotetext{
${ }^{21}$ Similar to Rajan and Zingales (1998) and Fisman and Love (2003), we interpret the US data on trade credit as representative of the inherent use of trade credit by firms in a given industry. We use Compustat data from 1990 to 2006 to construct this measure.
} 
Where $Y_{\mathrm{i}, \mathrm{t}}$ equals either financial (leverage, cash, accounts payables or receivables) or real outcomes (firm investment and profit). High TC Accessk equals an indicator set to one for a firm in 3-digit ISIC industry $k$ in which the time to make payments exceeds that of the time to receive payments. The coefficient $\beta_{1}$ measures the effect of exposure to the tax treatment for industries where trade credit leaves a financing gap (e.g., payments come in after 45 days but are due in just 30), whereas $\beta_{4}$ allows us to test for differential effects across industries. The sum of the two coefficients $\left(\beta_{1}+\beta_{4}\right)$ estimates the effect of the tax shock for firms in industries where trade credit effectively can substitute for bank liquidity.

Tables 6 and 7 report financial outcomes. Bank debt declines with exposure to the tax shock, consistent with Table 3. And, importantly, the decline in bank debt is similar across industries (Table 6, columns 1-3). That is, there is no heterogeneity in the treatment effect on short-term bank debt by industry. In contrast, the effect of exposure to the bank-tax shock on cash does differ across industries. For those with High TC Access, we find no change in cash (i.e., $\beta_{1}+\beta_{4}$ is not significant), as shown in Table 6, columns 4-6. In contrast, cash increases significantly in industries without High TC Access $\left(\beta_{1}>0\right)$. Table 7 reports the opposite patterns for trade credit. We find a large increase in accounts payable in industries with High TC Access $\left(\beta_{1}+\beta_{4}>0\right)$ but no effect where access is low $\left(\beta_{1}=0\right)$. Thus, some firms substitute into trade credit when short-term bank credit becomes expensive; this allows them to manage liquidity without raising cash. Others - those where trade credit frictions are substantial - instead must increase their buffer stock of cash.

Is the increase in cash costly? Table 8 suggests that it is. While we find no changes in profits, investment behavior differs sharply across industries. Firms without High TC Access cut investment, while firms with High TC Access do not. From equation (3): $\beta_{1}>0$ but $\beta_{1}+\beta_{4}=0$. 
So, firms unable to substitute from bank credit into trade credit both increase cash and cut investment. Investment rates fall, presumably, because raising the buffer stock of cash to replace short-term bank loans diverts internal funds away from investment (and external funds are costly). ${ }^{22}$ In contrast, firms with High TC Access are able to increase their use of accounts payable, thereby limiting the need to raise cash and avoiding the investment distortions that would otherwise occur.

\section{Results: Effects on the Cost of Trade Credit}

We have shown that a shock to the cost of short-term bank credit leads to increased trade credit that is concentrated among firms with an elastic supply of trade credit (i.e., industries where High TC Access = 1). We now trace these effects on the cost (or price) of trade credit. As highlighted in the literature (e.g. Petersen and Rajan (1994), Giannetti et al (2011)), foregone discounts are the predominant cost of trade credit. Thus, if higher demand for trade credit follows from the bank-tax shock, early payment discounts should decline and the cost of inputs should increase. We test this notion with both aggregate and firm-level data.

First, since we cannot observe early payment discounts at firm level, we collect data on a separate, albeit much smaller, sample of firms that are required to report additional financial statements information, including early payment discounts on sales. ${ }^{23}$ Although this sample is significantly smaller (we collect data available for 156 distinct firms, relative to over 12 thousand in our main sample), we show in Figure 5 that the percentage of early payment

\footnotetext{
${ }^{22}$ Increasing the cash buffer following the trade shock requires financing, which we presume displaces investment. Once the cash stock reaches a new higher level, however, investment ought to return to its old level. We are not able to test this effectively because not enough time has passed since the tax law change.

${ }^{23}$ Companies that issue publicly traded securities are required to report financial statements data to Colombia's Financial Superintendence (Superintendencia Financiera). Although these companies are required to report financial data using a similar reporting format as in our sample, they have the disadvantage that balance sheet items are not separated into short-term or long-term accounts, which is a key feature we exploit in our private firms' sample.
} 
discounts relative to total sales declines right after the shock to the cost of short-term bank debt. The average early payment discount over sales falls from an average of $0.26 \%$ between 2006 and 2010 to an average of $0.22 \%$ in the post-shock period (2011 to 2014). This suggest that as firms demand more trade credit, they forgo early payment discounts (increasing the cost of trade credit), which ultimately compensates the supplier for the provision of liquidity.

Second, and back to our large sample of firms, we build on the notion that foregone discounts are the main cost of trade credit and, similar to Gianetti et al (2011), we proxy it using the ratio of cost of goods sold (COGS) to sales. This variable should capture, even if roughly, the effect of changes in the cost of trade credit: foregone discounts should lead to a higher cost of inputs. We report regression results for equations (2) and (3) using costs of goods over sales as our outcome in Table 9. Panel A first shows that more exposure to the tax shock - which leads to increased accounts payable - appears to have a positive effect on the cost of trade credit $\left(\right.$ LnSales $_{i} \times$ AboveCutoff $_{i} \times$ Post $_{t}$ enters positively in column 1$)$. However, this baseline result loses statistical significance when we add control variables (columns 2 and 3).

In Panel B of Table 9, we introduce the interactions with High TC Access, as in equation (3). Where trade credit offers a poor substitute for short-term bank loans to manage liquidity, the cost of inputs seems to increase with the tax shock $\left(\beta_{1}>0\right)$, although the result loses significance when we add industry $\times$ time effects. In contrast, where trade credit is a better substitute for bank liquidity, the effect is close to zero. These results, together with the earlier ones, suggest that if trade credit supply elasticity is low (i.e. when High TC Access $=0$ ), an increase in trade credit demand has a positive effect on prices, while quantity remains largely unchanged. In contrast, where supply of trade credit is elastic (i.e. High TC Access = 1), an increase in demand has a much smaller effect on the price of trade credit, while quantity goes up 
significantly more. That said, these results should be interpreted with caution; the firm-level measure of the cost of trade credit is quite imprecise, as it pools with everything else that determines a firm's cost of goods sold.

\section{CONCLUSIONS}

Bank credit lines and very short-term loans offer liquidity to firms and limit the need to hold cash. Our results suggest that some firms can avoid holding larger buffers of cash when short-term bank credit becomes more expensive by substituting into trade credit. Identifying this substitution has been challenging in the literature, but we can exploit a tax shock in Colombia that penalizes very short-term bank loans. We show that substitution away from banks and into trade credit is important, as it allows firms to avoid the real investment reductions that we find in industries where access to trade credit is constrained. Trade credit is thus an important alternate source of liquidity that can insulate firms from bank liquidity shocks. Unlike much of the existing literature, we can analyze a shock that affects very short-term bank credit used for liquidity without feeding back into the long-term credit role of banks.

Our paper also highlights a pervasive theme in the empirical literature, which is the fundamental tradeoff between tight identification vs. generality, sometimes called 'external validity'. We certainly recognize limitations from concern over external validity, as our tax shock happens in an unusual setting that has already adapted to a broad bank transaction tax. Yet the key finding - that trade credit can substitute for bank liquidity and thereby avoid real distortions - is consistent with other broader but less well-identified settings. For example, Garcia-Appendini and Montoriol-Garriga (2013) show that trade credit supplied by cash-rich firms increases around the 2008 Financial Crisis. They argue that the increase reflects 
substitution motivated by the declining supply of liquidity from banks. Our study extends theirs because the tax shock in Colombia is very precise - it affects only very short-term bank loans, while leaving other potentially confounding variables like investment demand or changes in the supply of long-term bank loans unaffected. Our study thus helps mitigate identification concerns with their study, while their study helps mitigate external validity concerns with ours. 


\section{REFERENCES}

Acharya, V. V., Almeida, H., \& Campello, M. (2013). Aggregate risk and the choice between cash and lines of credit. The Journal of Finance, 68(5), 2059-2116.

Amberg, Niklas, Tor Jacobsen, Eric von Schedvin, and Robert Townsend, 2016 "Curbing Shocks to Corporate Liquidity: The Role of Trade Credit,” working paper, May 2016.

Arbeláez, M., Burman, L., \& Zuluaga, S. (2005). The bank debit tax in Colombia. Fiscal Reform in Colombia, 29-92.

Barrot, Jean-Noel, 2016, “Trade Credit and Industry Dynamics: Evidence from Trucking Firms,” Journal of Finance 71(5), 1975-2016.

Becker, B. (2007). Geographical segmentation of US capital markets. Journal of Financial economics, 85(1), 151-178.

Breza, Emily and Andres Lieberman, 2016, "Financial Contracting and Organizational Form: Evidence from the Regulation of Trade Credit, Journal of Finance, forthcoming.

Brunnermeier, M. K. (2009). Deciphering the liquidity and credit crunch 2007-2008. The Journal of economic perspectives, 23(1), 77-100.

Burkart, M., \& Ellingsen, T. (2004). In-kind finance: A theory of trade credit. The American economic review, 94(3), 569-590.

Card, D., Lee, D., Pei, Z., \& Weber, A. (2012). Nonlinear policy rules and the identification and estimation of causal effects in a generalized regression kink design (No. w18564). National Bureau of Economic Research.

Cunat, Vicente, 2007, “Trade Credit: Suppliers as Debt Collectors and Insurance Providers,” Review of Financial Studies 20(2).

Demiroglu, C., \& James, C. (2011). The use of bank lines of credit in corporate liquidity management: A review of empirical evidence. Journal of Banking \& Finance, 35(4), 775-782.

Diamond, D. W. (1991). Debt maturity structure and liquidity risk. The Quarterly Journal of Economics, 709-737.

Duchin, Ran, Ozbas and Sensoy, 2010, "Costly External Finance, Corporate Investment, and the Subprime Mortgage Credit Crisis,” Journal of Financial Economics.

Fisman, R., \& Love, I. (2003). Trade credit, financial intermediary development, and industry growth. The Journal of Finance, 58(1), 353-374. 
García-Appendini, Emilia and Judit Montoriol-Garriga, 2013 "Firms as liquidity providers: Evidence from the 2007-2008 financial crisis,” Journal of Financial Economics 109 (1), 272291.

Gatev, E., \& Strahan, P. E. (2006). Banks' advantage in hedging liquidity risk: Theory and evidence from the commercial paper market. The Journal of Finance, 61(2), 867-892.

Gatev, E., \& Strahan, P. E. (2009). Liquidity Risk and Syndicate Structure, Journal of Financial Economics 93(3), 490-504.

Gatev, E., Schuermann, T., \& Strahan, P. E. (2009). Managing bank liquidity risk: How depositloan synergies vary with market conditions. Review of Financial studies, 22(3), 995-1020.

Gilje, E. P., Loutskina, E., \& Strahan, P. E. (2016). Exporting liquidity: Branch banking and financial integration. The Journal of Finance.

Giannetti, Mariassunta, Mike Burkhart and Tor Ellingsen, 2011, "What you Sell is What you Lend? Explaining Trade Credit Contracts,” Review of Financial Studies 24(4), 1261-98.

Ivashina, V., \& Scharfstein, D. (2010). Bank lending during the financial crisis of 2008. Journal of Financial economics, 97(3), 319-338.

Jensen, M. C. (1986). Agency cost of free cash flow, corporate finance, and takeovers. Corporate Finance, and Takeovers. American Economic Review, 76(2).

Jiménez. G., Lopez J., and and J. Saurina. (2009). Empirical analysis of corporate credit lines,” 2009, Review of Financial Studies 22, 5069-5098.

Kashyap, A. K., Rajan, R., \& Stein, J. C. (2002). Banks as liquidity providers: An explanation for the coexistence of lending and deposit-taking. The Journal of Finance, 57(1), 33-73.

Kleibergen, F., \& Paap, R. (2006). Generalized reduced rank tests using the singular value decomposition. Journal of econometrics, 133(1), 97-126.

Lastrapes, W. D., \& Selgin, G. (1997). The check tax: Fiscal folly and the great monetary contraction. The Journal of Economic History, 57(04), 859-878.

Lins, K. V., Servaes, H., \& Tufano, P. (2010). What drives corporate liquidity? An international survey of cash holdings and lines of credit. Journal of financial economics, 98(1), 160-176.

Merrouche, O., \& Nier, E. (2012). Payment systems, inside money and financial intermediation. Journal of Financial Intermediation, 21(3), 359-382.

Murfin, J., \& Njoroge, K. (2015). The implicit costs of trade credit borrowing by large firms. Review of Financial Studies, 28(1), 112-145. 
Ng, C. K., Smith, J. K., \& Smith, R. L. (1999). Evidence on the determinants of credit terms used in interfirm trade. The Journal of Finance, 54(3), 1109-1129.

Peek, J., \& Rosengren, E. S. (2000). Collateral damage: Effects of the Japanese banking crisis on real investment in the U.S. The American Economic Review, 90(1), 30-45.

Petersen, Mitchell A., and Raghuram G. Rajan. "Trade credit: theories and evidence." Review of financial studies 10.3 (1997): 661-691.

Rajan, R. G. (1998). The past and future of commercial banking viewed through an incomplete contract lens. Journal of Money, Credit and Banking, 524-550.

Roberts, Michael R. and Whited, Toni M., Endogeneity in Empirical Corporate Finance (October 5, 2012). Simon School Working Paper No. FR 11-29. Available at SSRN:

http://ssrn.com/abstract=1748604

Schaffer, M.E., 2010. xtivreg2: Stata module to perform extended IV/2SLS, GMM and AC/HAC, LIML and k-class regression for panel data models.

http://ideas.repec.org/c/boc/bocode/s456501.html

Scharlemann, T. C., \& Shore, S. H. (2016). The Effect of Negative Equity on Mortgage Default: Evidence From HAMP's Principal Reduction Alternative. Review of Financial Studies, hhw034.

Schwartz, R. A. (1974). An economic model of trade credit. Journal of financial and quantitative analysis, 9(04), 643-657.

Smith, J. K. (1987). Trade credit and informational asymmetry. The Journal of Finance, 42(4), 863-872.

Stock, J. H., \& Yogo, M. (2005). Testing for weak instruments in linear IV regression. Identification and inference for econometric models: Essays in honor of Thomas Rothenberg.

Stohs, M. H., \& Mauer, D. C. (1996). The determinants of corporate debt maturity structure. Journal of Business, 279-312.

Sufi, A. (2009). Bank lines of credit in corporate finance: An empirical analysis. Review of Financial Studies, 22(3), 1057-1088.

Wilner, Benjamin S., 2000, “The Exploitation of Relatonships in Financial Distress: The Case of Trade Credit,” Journal of Finance 55(1), 153-78.

Yun, H. (2009). The choice of corporate liquidity and corporate governance. Review of Financial Studies, 22(4), 1447-1475. 


\section{Figure 1. BAD Tax Rate and Annual Tax Revenue Collected}

This figure plots the evolution of the BAD tax rate (left y-axis) and the fiscal revenues from the BAD tax scaled by GPD (right y-axis) through time. Fiscal revenues data are from Colombia's revenue agency (Departamento de Impuestos y Aduanas Nacionales, DIAN).

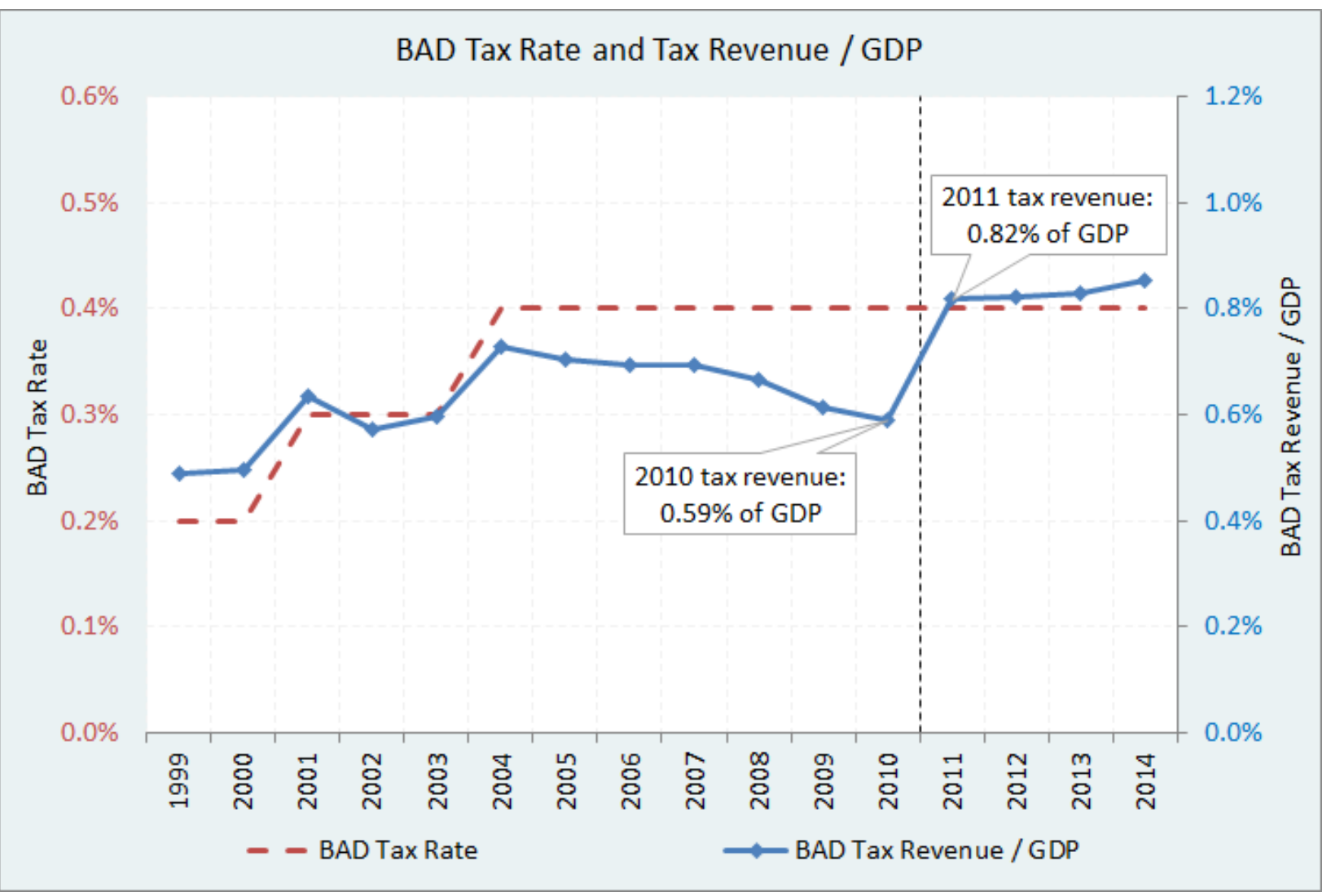




\section{Figure 2. Effect of 2011 Tax Law Change on the 'All-In’ Term Structure of Bank Debt}

This figure illustrates the increase in the cost of debt on an annualized basis stemming from the 2011 tax law change, as a function of a loan's maturity. For simplicity, the red dashed line is set constant at 8.0\%, reflecting a flat term structure of interest rates. The blue solid line depicts the 'all-in' cost of debt at after the cost of the tax is included in the loan's cash flow. The tax law change adds a cost of $0.4 \%$ to every loan, irrespective of its maturity; thus the 'all-in' annualized cost for shorter term loans increases significantly more than for longer term debt. For example, the 'all-in' cost for a 5-day loan is equal to: $[(1+8.0 \% * 5 / 365) *(1+0.4 \%)-1] *(365 / 5)=37.2 \%$, while the 'all-in' cost for a 1 -year loan is equal to: $[(1+8.0 \% * 365 / 365) *(1+0.4 \%)-1] *(365 / 365)=8.4 \%$

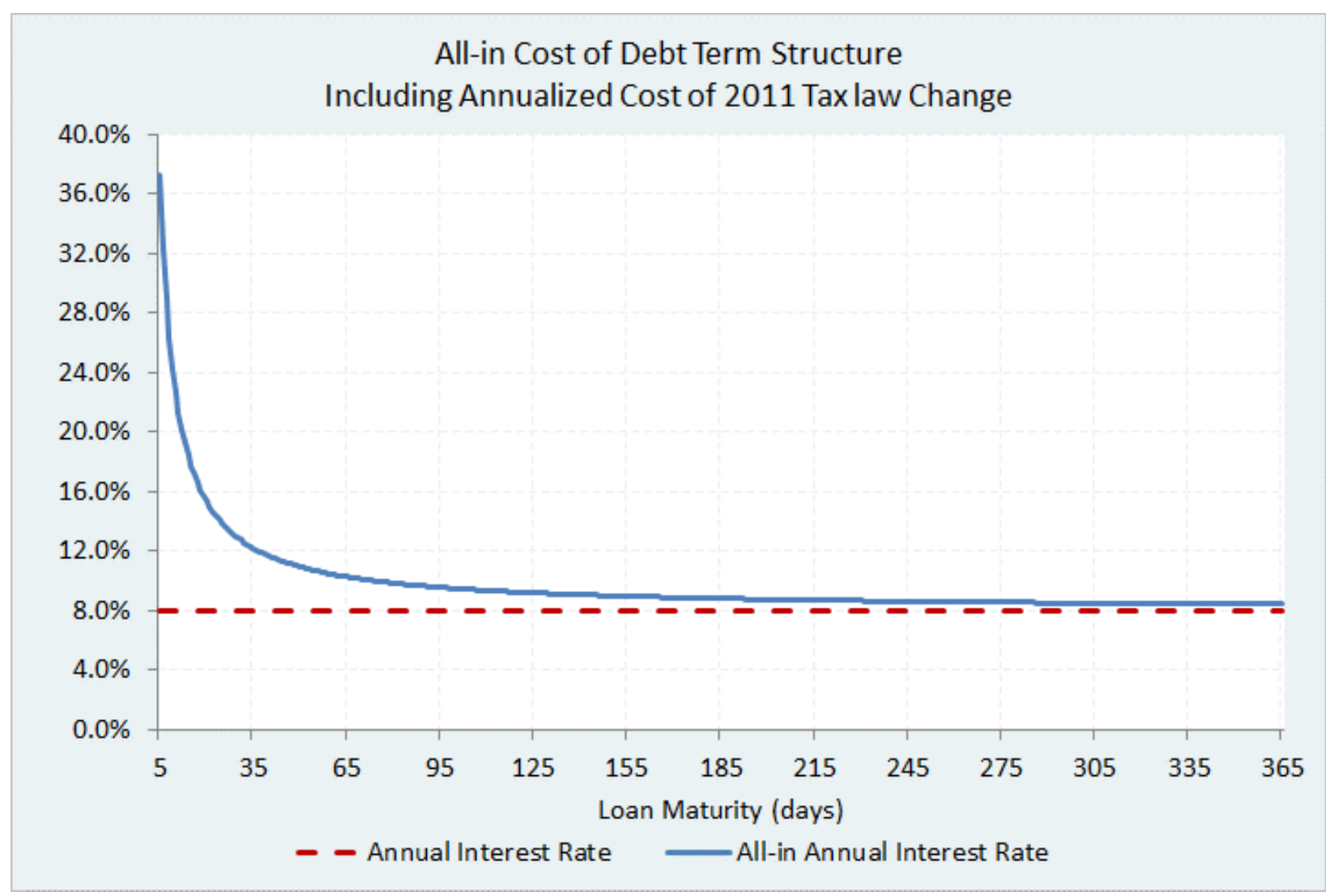


Figure 3. Aggregate Monthly Issuance of Treasury Facilities around 2011 Tax Law Change

This figure plots the aggregate monthly issuance of Treasury Facilities around the 2011 tax law change. All numbers are in COP millions. Aggregate data are from Colombia's central bank (Banco de la República) and include all Treasury Facility loans issued in Colombia.

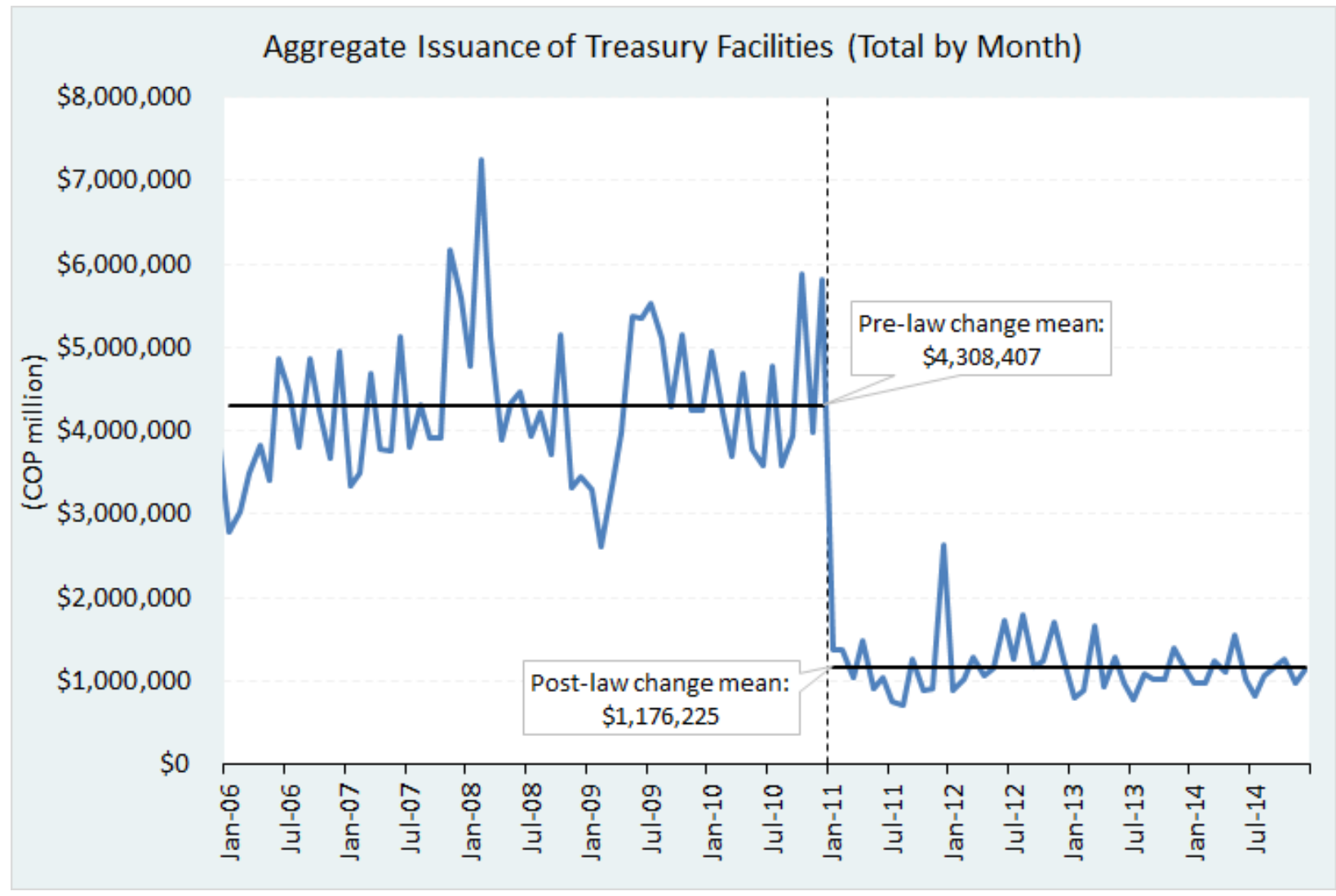




\section{Figure 4. Issuance of Short Term Debt (0 to 60 days) Around the Sales Cutoff}

This figure plots the average annual issuance of short term bank loans with maturities under 60 days per dollar of assets against firm sales in panel A and log of firm sales in panel B. Each plot depicts this relationship before the tax law change in 2011 on the left, and after 2011 on the right.

Panel A. Running variable: Sales - Cutoff
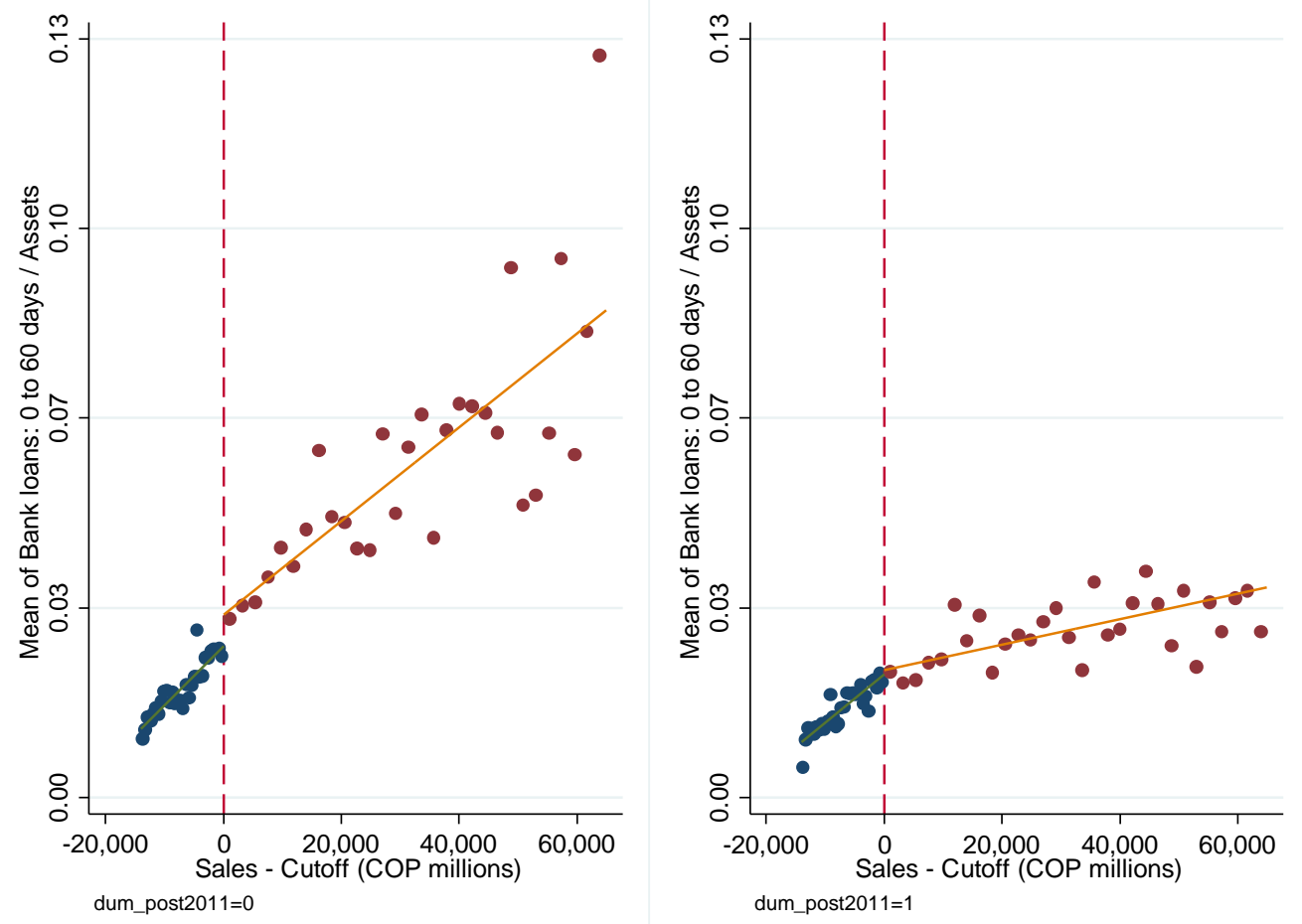
Panel B. Running variable: Ln(Sales - Cutoff)
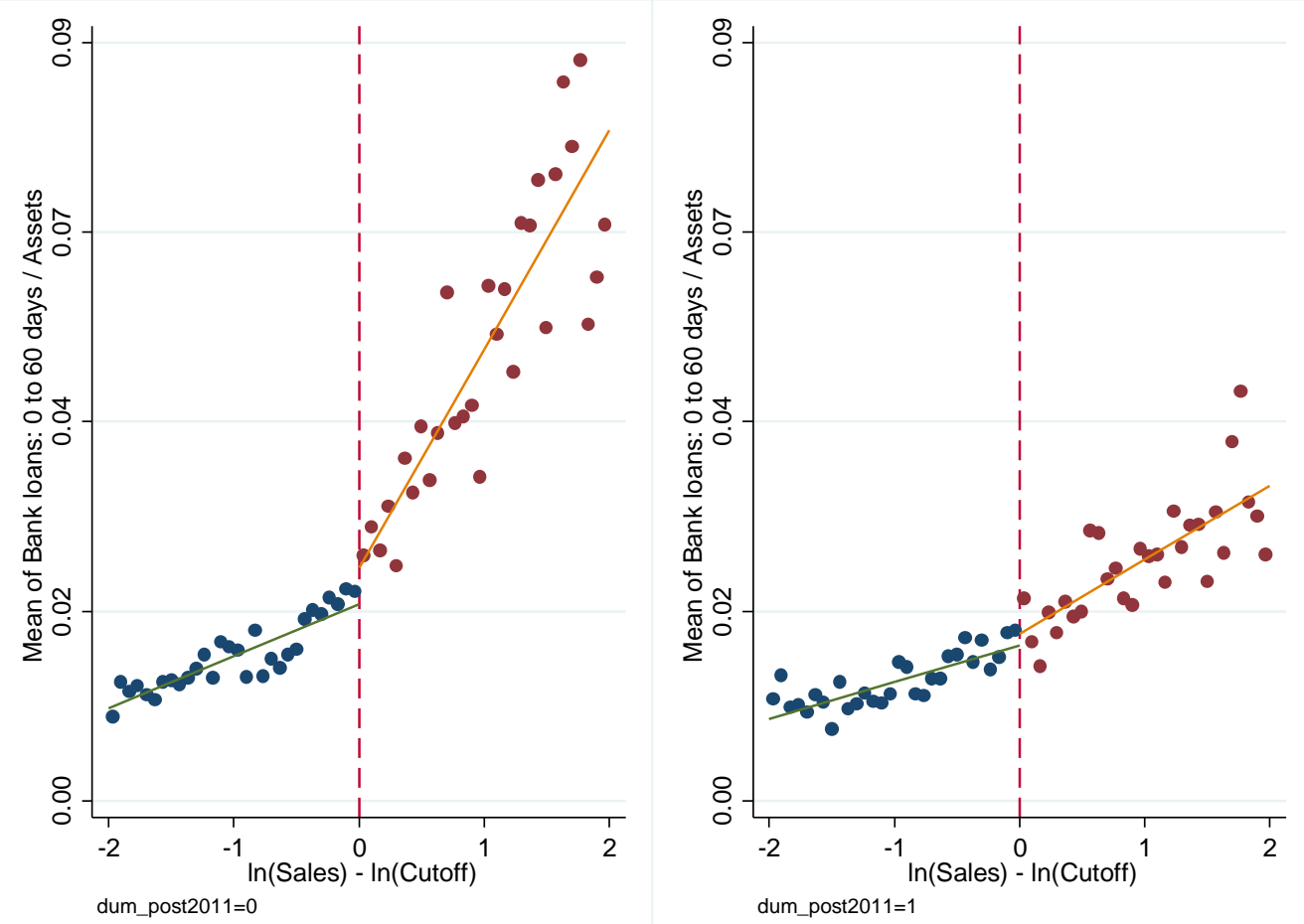


\section{Figure 5. Early Payment Discounts on Sales / Sales around 2011 Tax Law Change}

This figure plots sales discounts over total sales between 2006 and 2014 for a separate sample of 156 Colombian firms that issue public securities and are thus required to report additional financial statements items not reported by our larger sample of private firms, including the COP amount of early payment discounts provided on sales. The graph plots the average sales discount over total sales per year (we account for differences across firms by estimating the average per year in a regression that includes firm fixed effects).

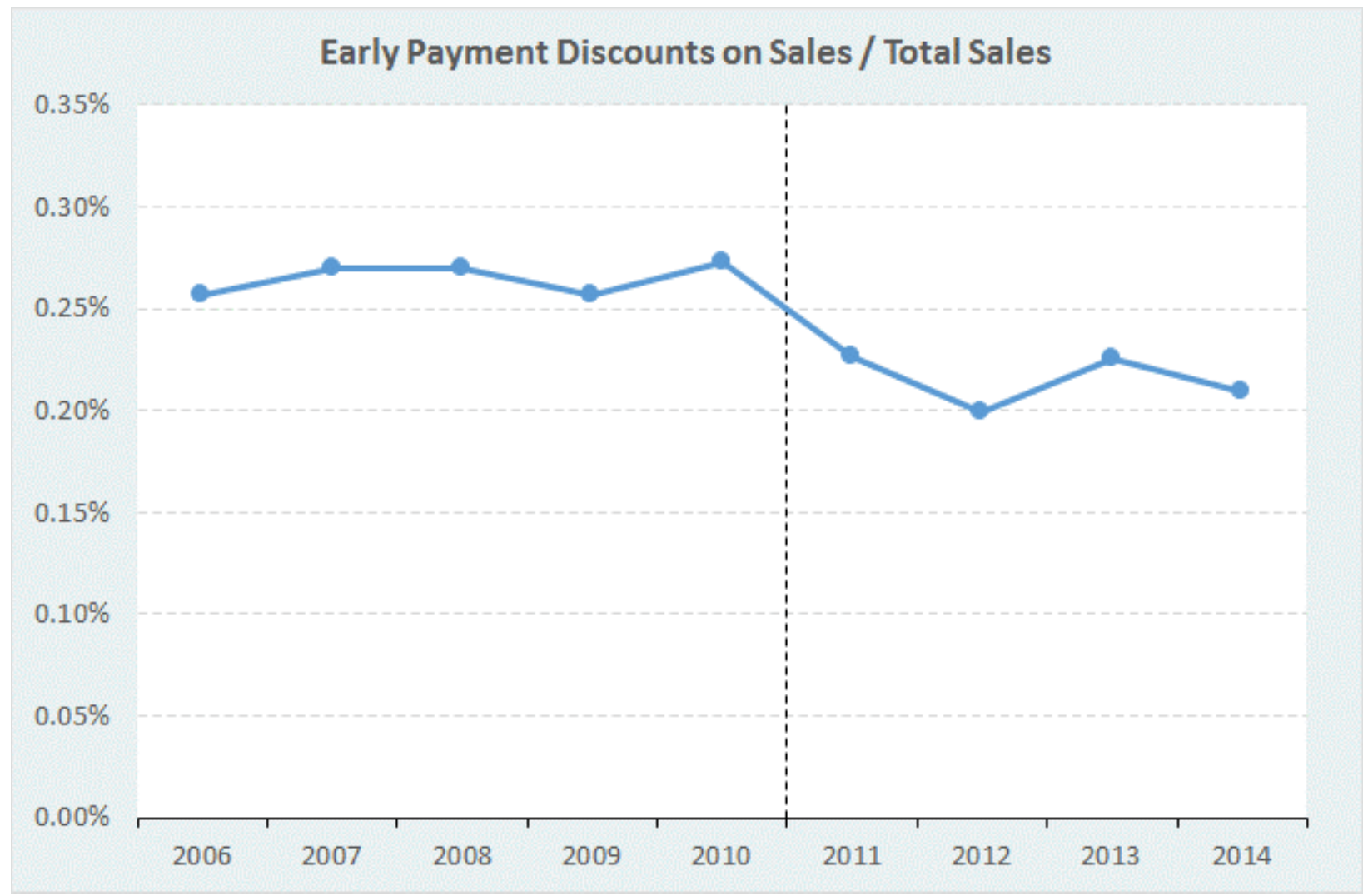




\section{Table 1. Summary Statistics}

This table reports summary statistics (means and standard deviation) for our sample of firms during the period 2008-2013. The data source stems from Colombia's Corporations Superintendence (Superintendencia de Sociedades). Summary statistics are divided by firms below and above the sales cutoff of COP 15,000 million (approximately \$5 million).

\begin{tabular}{|c|c|c|c|c|}
\hline & \multicolumn{2}{|c|}{ Firms Below Sales Cutoff } & \multicolumn{2}{|c|}{ Firms Above Sales Cutoff } \\
\hline & Mean & Std. Deviation & Mean & Std. Deviation \\
\hline Bank Debt / Assets & 0.146 & 0.156 & 0.194 & 0.179 \\
\hline ST Bank Debt (1 year or less) / Assets & 0.088 & 0.118 & 0.129 & 0.149 \\
\hline LT Bank Debt (more than 1 year) / Assets & 0.058 & 0.111 & 0.065 & 0.109 \\
\hline Accounts Payable / Assets & 0.127 & 0.148 & 0.147 & 0.151 \\
\hline Accounts Receivable / Assets & 0.209 & 0.182 & 0.232 & 0.179 \\
\hline Cash Holdings / Assets & 0.072 & 0.101 & 0.057 & 0.080 \\
\hline ST Debt Issuance (0 to 60 days) / Assets & 0.015 & 0.051 & 0.039 & 0.093 \\
\hline Capex / Assets & 0.041 & 0.084 & 0.045 & 0.080 \\
\hline Profit Margin & 0.044 & 0.107 & 0.034 & 0.089 \\
\hline Asset Tangibility & 0.183 & 0.183 & 0.157 & 0.148 \\
\hline Asset Turnover & 1.471 & 1.134 & 1.962 & 1.640 \\
\hline Ln(Assets) & 15.358 & 0.922 & 17.288 & 1.304 \\
\hline Asset Growth & 0.157 & 0.321 & 0.162 & 0.309 \\
\hline Age & 19.290 & 11.804 & 24.633 & 15.786 \\
\hline Number of Firm-Years & & 49,004 & & 18,208 \\
\hline Number of Distinct Firms & & 9,418 & & 3,231 \\
\hline
\end{tabular}




\section{Table 2. Effect of 2011 Law Change on the Issuance of Short Term Debt (0 to 60 days)}

This table reports panel regressions of the issuance of short term debt (maturities between 0 and 60 days) on our instrument: the triple interaction between firm (log) sales, an indicator equal to one for firms above the cutoff before the tax change (reflecting the increased slope above the cutoff), and an indicator equal to one after the 2011 tax change (reflecting the slope's flattening). Columns 1 to 3 report the 'first stage' regressions. Columns 4 to 6 report placebo regressions where interactions with a 2010-year indicator variable (the year before the shock) are included. All regressions include time and firm fixed effects, columns 2 and 5 add firm controls, and columns 3 and 6 add Industry $\times$ Year fixed effects. Standard errors clustered by firm (in parentheses). ${ }^{* * *}, * *$, and * indicates significance at the $1 \%, 5 \%$ and $10 \%$ level, respectively.

\begin{tabular}{|c|c|c|c|c|c|c|}
\hline & \multicolumn{6}{|c|}{ Issuance of ST Debt (0 to 60 days) } \\
\hline & \multicolumn{3}{|c|}{ First Stage } & \multicolumn{3}{|c|}{ Placebo Test } \\
\hline & $(1)$ & (2) & (3) & $(4)$ & (5) & $(6)$ \\
\hline Post 2011 & - & - & - & - & - & - \\
\hline Ln(Sales) & - & - & - & - & - & - \\
\hline Above Cutoff & - & - & - & - & - & - \\
\hline Ln(Sales) * Above Cutoff & - & - & - & - & - & - \\
\hline Ln(Sales) * Post 2011 & $\begin{array}{l}-0.001 * \\
(0.001)\end{array}$ & $\begin{array}{c}-0.002 * * * \\
(0.001)\end{array}$ & $\begin{array}{c}-0.002 * * * \\
(0.001)\end{array}$ & $\begin{array}{l}-0.002 * \\
(0.001)\end{array}$ & $\begin{array}{c}-0.002^{* *} \\
(0.001)\end{array}$ & $\begin{array}{c}-0.002 * * \\
(0.001)\end{array}$ \\
\hline Above Cutoff * Post 2011 & $\begin{array}{c}-0.006 * * \\
(0.002)\end{array}$ & $\begin{array}{c}-0.006^{* *} \\
(0.003)\end{array}$ & $\begin{array}{c}-0.005^{* *} \\
(0.003)\end{array}$ & $\begin{array}{c}-0.007 * * \\
(0.003)\end{array}$ & $\begin{array}{c}-0.006^{* *} \\
(0.003)\end{array}$ & $\begin{array}{c}-0.006^{* *} \\
(0.003)\end{array}$ \\
\hline Ln(Sales) * Above Cutoff * Post 2011 & $\begin{array}{c}-0.012^{* * *} \\
(0.002)\end{array}$ & $\begin{array}{c}-0.012 * * * \\
(0.002)\end{array}$ & $\begin{array}{c}-0.013^{* * *} \\
(0.002)\end{array}$ & $\begin{array}{c}-0.013^{* * *} \\
(0.002)\end{array}$ & $\begin{array}{c}-0.013^{* * *} \\
(0.002)\end{array}$ & $\begin{array}{c}-0.013 * * * \\
(0.002)\end{array}$ \\
\hline 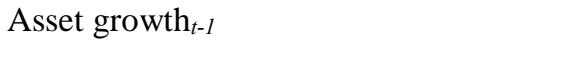 & & $\begin{array}{c}-0.001 \\
(0.001)\end{array}$ & $\begin{array}{c}-0.001 \\
(0.001)\end{array}$ & & $\begin{array}{c}-0.001 \\
(0.001)\end{array}$ & $\begin{array}{c}-0.001 \\
(0.001)\end{array}$ \\
\hline $\operatorname{Ln}(\text { Assets })_{t-1}$ & & $\begin{array}{c}0.000 \\
(0.002)\end{array}$ & $\begin{array}{l}-0.001 \\
(0.002)\end{array}$ & & $\begin{array}{l}-0.001 \\
(0.002)\end{array}$ & $\begin{array}{c}-0.001 \\
(0.002)\end{array}$ \\
\hline Asset tangibility $y_{t-1}$ & & $\begin{array}{c}0.002 \\
(0.004)\end{array}$ & $\begin{array}{c}0.002 \\
(0.004)\end{array}$ & & $\begin{array}{c}0.002 \\
(0.004)\end{array}$ & $\begin{array}{c}0.002 \\
(0.004)\end{array}$ \\
\hline Asset turnover $t_{t-1}$ & & $\begin{array}{c}0.003^{* * *} \\
(0.001)\end{array}$ & $\begin{array}{c}0.003^{* * *} \\
(0.001)\end{array}$ & & $\begin{array}{c}0.003^{* * *} \\
(0.001)\end{array}$ & $\begin{array}{c}0.003^{* * *} \\
(0.001)\end{array}$ \\
\hline Ln(Firm Age $)_{t-1}$ & & $\begin{array}{c}0.000 \\
(0.003)\end{array}$ & $\begin{array}{c}0.000 \\
(0.003)\end{array}$ & & $\begin{array}{c}0.000 \\
(0.003)\end{array}$ & $\begin{array}{c}0.000 \\
(0.003)\end{array}$ \\
\hline${\text { GDP } \text { growth }_{t-1} * \operatorname{Ln}(\text { Sales })}$ & & $\begin{array}{c}0.071^{* * *} \\
(0.012)\end{array}$ & $\begin{array}{c}0.077 * * * \\
(0.012)\end{array}$ & & $\begin{array}{c}0.071^{* * *} \\
(0.013)\end{array}$ & $\begin{array}{c}0.079 * * * \\
(0.013)\end{array}$ \\
\hline Ln(Sales) * Year $=2010$ & & & & $\begin{array}{l}-0.001 \\
(0.001)\end{array}$ & $\begin{array}{c}0.001 \\
(0.001)\end{array}$ & $\begin{array}{c}0.001 \\
(0.001)\end{array}$ \\
\hline Above Cutoff * Year $=2010$ & & & & $\begin{array}{c}-0.002 \\
(0.003)\end{array}$ & $\begin{array}{c}-0.001 \\
(0.003)\end{array}$ & $\begin{array}{c}-0.001 \\
(0.003)\end{array}$ \\
\hline Ln(Sales) * Above Cutoff * Year=2010 & & & & $\begin{array}{c}-0.002 \\
(0.002)\end{array}$ & $\begin{array}{c}-0.001 \\
(0.002)\end{array}$ & $\begin{array}{c}-0.001 \\
(0.002)\end{array}$ \\
\hline Year FE & Yes & Yes & Yes & Yes & Yes & Yes \\
\hline Firm FE & Yes & Yes & Yes & Yes & Yes & Yes \\
\hline Industry $\times$ Year FE & No & No & Yes & No & No & Yes \\
\hline Observations & 61,461 & 56,535 & 56,535 & 61,461 & 56,535 & 56,535 \\
\hline $\mathrm{r}^{2}$ (within Firm FE) & 0.027 & 0.032 & 0.036 & 0.028 & 0.032 & 0.036 \\
\hline
\end{tabular}




\section{Table 3. Effect of 2011 Law Change on Leverage and Cash Holdings}

This table reports reduced form regressions for leverage and cash holdings. Reduced form regressions for leverage (panel A, columns 1 to 3 ) and cash holdings (panel A, columns 4 to 6 ) show the effect of a shock to the cost of short-term liquidity loans based on the triple interaction term: "Ln(Sales) * Above Cutoff * Post 2011". Panel B shows the decomposition of the effect on leverage by maturity: columns 1 to 3 show the effect on short term debt (one year or less in maturity) and columns 4 to 6 show the effect on long term debt (more than a year in maturity). All

regressions include time and firm fixed effects, columns 2 and 5 add firm controls, and columns 3 and 6 add Industry $\times$ Year fixed effects. Note that the time and firm fixed effects absorb the direct effects of $L n$ (Sales), Above Cutoff and Post 2011. Standard errors clustered by firm (in parentheses). ${ }^{* *},{ }^{* *}$, and ${ }^{*}$ indicates significance at the $1 \%, 5 \%$ and $10 \%$ level, respectively.

Panel A. Leverage and Cash Holdings

\begin{tabular}{|c|c|c|c|c|c|c|}
\hline \multirow[t]{2}{*}{ Dependent Variable: } & \multicolumn{3}{|c|}{ Leverage $=$ Bank Debt $/$ Assets } & \multicolumn{3}{|c|}{ Cash / Assets } \\
\hline & $(1)$ & $(2)$ & $(3)$ & $(4)$ & $(5)$ & $(6)$ \\
\hline Ln(Sales) * Post 2011 & $\begin{array}{c}0.005^{* * *} \\
(0.002)\end{array}$ & $\begin{array}{c}0.002 \\
(0.002)\end{array}$ & $\begin{array}{c}0.002 \\
(0.002)\end{array}$ & $\begin{array}{c}-0.003 * * * \\
(0.001)\end{array}$ & $\begin{array}{c}-0.003^{* *} \\
(0.001)\end{array}$ & $\begin{array}{c}-0.003 * * \\
(0.001)\end{array}$ \\
\hline Above Cutoff * Post 2011 & $\begin{array}{c}0.004 \\
(0.004)\end{array}$ & $\begin{array}{c}0.001 \\
(0.004)\end{array}$ & $\begin{array}{c}0.001 \\
(0.004)\end{array}$ & $\begin{array}{c}0.003 \\
(0.002)\end{array}$ & $\begin{array}{c}0.005^{* *} \\
(0.002)\end{array}$ & $\begin{array}{c}0.005^{* *} \\
(0.002)\end{array}$ \\
\hline Ln(Sales) * Above Cutoff * Post 2011 & $\begin{array}{c}-0.012 * * * \\
(0.002)\end{array}$ & $\begin{array}{c}-0.009 * * * \\
(0.003)\end{array}$ & $\begin{array}{c}-0.008 * * * \\
(0.003)\end{array}$ & $\begin{array}{c}0.005^{* * *} \\
(0.001)\end{array}$ & $\begin{array}{c}0.004 * * \\
(0.002)\end{array}$ & $\begin{array}{c}0.004^{* *} \\
(0.002)\end{array}$ \\
\hline Year FE & Yes & Yes & Yes & Yes & Yes & Yes \\
\hline Firm FE & Yes & Yes & Yes & Yes & Yes & Yes \\
\hline Firm Controls & No & Yes & Yes & No & Yes & Yes \\
\hline Industry $\times$ Year FE & No & No & Yes & No & No & Yes \\
\hline Observations & 65,243 & 56,535 & 56,535 & 65,243 & 56,535 & 56,535 \\
\hline $\mathrm{r}^{2}$ (within Firm FE) & 0.004 & 0.020 & 0.022 & 0.002 & 0.008 & 0.010 \\
\hline
\end{tabular}


Panel B. Short term and Long Term Leverage and Cash Holdings

\begin{tabular}{|c|c|c|c|c|c|c|}
\hline \multirow{2}{*}{ Dependent Variable: } & \multicolumn{3}{|c|}{ Short-term Bank Debt / Assets ( $<1$ year) } & \multicolumn{3}{|c|}{ Long-term Bank Debt / Assets ( $>=1$ year) } \\
\hline & $(1)$ & $(2)$ & (3) & (4) & (5) & $(6)$ \\
\hline Ln(Sales) * Post 2011 & $\begin{array}{c}0.004^{* * *} \\
(0.001)\end{array}$ & $\begin{array}{c}0.004^{* *} \\
(0.002)\end{array}$ & $\begin{array}{c}0.003^{* *} \\
(0.002)\end{array}$ & $\begin{array}{c}0.000 \\
(0.001)\end{array}$ & $\begin{array}{c}-0.001 \\
(0.001)\end{array}$ & $\begin{array}{l}-0.002 \\
(0.001)\end{array}$ \\
\hline Above Cutoff * Post 2011 & $\begin{array}{l}-0.001 \\
(0.003)\end{array}$ & $\begin{array}{c}-0.002 \\
(0.003)\end{array}$ & $\begin{array}{c}-0.002 \\
(0.003)\end{array}$ & $\begin{array}{c}0.005^{*} \\
(0.003)\end{array}$ & $\begin{array}{c}0.003 \\
(0.003)\end{array}$ & $\begin{array}{c}0.003 \\
(0.003)\end{array}$ \\
\hline Ln(Sales) * Above Cutoff * Post 2011 & $\begin{array}{c}-0.009 * * * \\
(0.002)\end{array}$ & $\begin{array}{c}-0.009 * * * \\
(0.002)\end{array}$ & $\begin{array}{c}-0.008 * * * \\
(0.002)\end{array}$ & $\begin{array}{l}-0.003 \\
(0.002)\end{array}$ & $\begin{array}{c}0.000 \\
(0.002)\end{array}$ & $\begin{array}{c}0.000 \\
(0.002)\end{array}$ \\
\hline Year FE & Yes & Yes & Yes & Yes & Yes & Yes \\
\hline Firm FE & Yes & Yes & Yes & Yes & Yes & Yes \\
\hline Firm Controls & No & Yes & Yes & No & Yes & Yes \\
\hline Industry $\times$ Year FE & No & No & Yes & No & No & Yes \\
\hline Observations & 65,243 & 56,535 & 56,535 & 65,243 & 56,535 & 56,535 \\
\hline $\mathrm{r}^{2}$ (within Firm FE) & 0.003 & 0.007 & 0.010 & 0.005 & 0.017 & 0.020 \\
\hline
\end{tabular}




\section{Table 4. Effect of 2011 Law Change on Trade Credit}

This table reports reduced form and regressions for accounts payable and accounts receivable. Reduced form regressions for accounts payable (columns 1 to 3) and accounts receivable (columns 4 to 6 ) show the effect of a shock to the cost of short-term liquidity loans based on the triple interaction term: "Ln(Sales) * Above Cutoff * Post 2011". All regressions include time and firm fixed effects, columns 2 and 5 add firm controls, and columns 3 and 6 add Industry $\times$ Year fixed effects. Standard errors clustered by firm (in parentheses). ${ }^{* * *}$, **, and ${ }^{*}$ indicates significance at the $1 \%, 5 \%$ and $10 \%$ level, respectively.

\begin{tabular}{|c|c|c|c|c|c|c|}
\hline \multirow[t]{2}{*}{ Dependent Variable: } & \multicolumn{3}{|c|}{ Accounts Payable / Assets } & \multicolumn{3}{|c|}{ Accounts Receivable / Assets } \\
\hline & $(1)$ & $(2)$ & $(3)$ & $(4)$ & $(5)$ & $(6)$ \\
\hline \multirow[t]{2}{*}{ Ln(Sales) * Post 2011} & $-0.004 * * *$ & -0.002 & -0.002 & $-0.004 * *$ & -0.001 & 0.000 \\
\hline & $(0.001)$ & $(0.001)$ & $(0.001)$ & $(0.001)$ & $(0.002)$ & $(0.002)$ \\
\hline \multirow[t]{2}{*}{ Above Cutoff * Post 2011} & -0.001 & 0.000 & 0.000 & -0.001 & -0.001 & -0.001 \\
\hline & $(0.003)$ & $(0.003)$ & $(0.003)$ & $(0.003)$ & $(0.003)$ & $(0.003)$ \\
\hline \multirow[t]{2}{*}{ Ln(Sales) * Above Cutoff * Post 2011} & $0.010^{* * *}$ & $0.007 * * *$ & $0.006^{* * *}$ & $0.007 * * *$ & $0.004 *$ & 0.003 \\
\hline & $(0.002)$ & $(0.002)$ & $(0.002)$ & $(0.002)$ & $(0.002)$ & $(0.002)$ \\
\hline Year FE & Yes & Yes & Yes & Yes & Yes & Yes \\
\hline Firm FE & Yes & Yes & Yes & Yes & Yes & Yes \\
\hline Firm Controls & No & Yes & Yes & No & Yes & Yes \\
\hline Industry $\times$ Year FE & No & No & Yes & No & No & Yes \\
\hline Observations & 65,243 & 56,535 & 56,535 & 65,243 & 56,535 & 56,535 \\
\hline$r^{2}$ (within Firm FE) & 0.017 & 0.021 & 0.024 & 0.013 & 0.024 & 0.030 \\
\hline
\end{tabular}




\section{Table 5. Effect of 2011 Law Change on Real Outcomes: Investment and Profitability}

This table reports reduced form regressions for Capex and profitability. Reduced form regressions for Capex (columns 1 to 3 ) and profitability (columns 4 to 6 ) show the effect of a shock to the cost of short-term liquidity loans based on the triple interaction term: "Ln(Sales) * Above Cutoff * Post 2011”. All regressions include time and firm fixed effects, columns 2 and 5 add firm controls, and columns 3 and 6 add Industry $\times$ Year fixed effects. Standard errors clustered by firm (in parentheses). ***, **, and * indicates significance at the $1 \%, 5 \%$ and $10 \%$ level, respectively.

\begin{tabular}{|c|c|c|c|c|c|c|}
\hline \multirow[t]{2}{*}{ Dependent Variable: } & \multicolumn{3}{|c|}{ Capex / Assets Al $_{1}$} & \multicolumn{3}{|c|}{ Profit Margin } \\
\hline & $(1)$ & $(2)$ & (3) & (4) & (5) & (6) \\
\hline \multirow[t]{2}{*}{ Ln(Sales) * Post 2011} & -0.001 & 0.001 & 0.000 & -0.002 & -0.001 & -0.001 \\
\hline & $(0.001)$ & $(0.001)$ & $(0.001)$ & $(0.001)$ & $(0.002)$ & $(0.002)$ \\
\hline \multirow{2}{*}{ Above Cutoff * Post 2011} & 0.003 & $0.005^{* *}$ & 0.003 & -0.001 & 0.001 & 0.000 \\
\hline & $(0.002)$ & $(0.002)$ & $(0.002)$ & $(0.002)$ & $(0.003)$ & $(0.003)$ \\
\hline \multirow[t]{2}{*}{ Ln(Sales) * Above Cutoff * Post 2011} & -0.003 & $-0.006 * * *$ & $-0.004^{* *}$ & 0.000 & -0.001 & 0.000 \\
\hline & $(0.002)$ & $(0.002)$ & $(0.002)$ & $(0.002)$ & $(0.002)$ & $(0.002)$ \\
\hline Year FE & Yes & Yes & Yes & Yes & Yes & Yes \\
\hline Firm FE & Yes & Yes & Yes & Yes & Yes & Yes \\
\hline Firm Controls & No & Yes & Yes & No & Yes & Yes \\
\hline Industry $\times$ Year FE & No & No & Yes & No & No & Yes \\
\hline Observations & 61,461 & 56,535 & 56,535 & 65,243 & 56,535 & 56,535 \\
\hline$r^{2}$ (within Firm FE) & 0.012 & 0.085 & 0.093 & 0.002 & 0.005 & 0.009 \\
\hline
\end{tabular}




\section{Table 6. Differential Effect on Industries with High TC Access: Leverage and Cash}

This table reports reduced form regressions for leverage (columns 1 to 3 ) and cash holdings (columns 4 to 6), exploring the differential effect of the shock (based on the triple interaction term: "Ln(Sales) * Above Cutoff * Post 2011") on firms in industries with positive net trade credit borrowing days (i.e. firms with High TC Access). Positive net trade credit borrowing days are calculated at the ISIC 3-digit level using Compustat data between 1990 and 2006. Panel A reports the reduced form regressions. Panel B reports an F-test evaluating whether the added effect of coefficients (a) + (b) is different from zero for each column. All regressions include time and firm fixed effects, columns 2 and 5 add firm controls, and columns 3 and 6 add Industry $\times$ Year fixed effects. Standard errors clustered by firm (in parentheses). ***, **, and * indicates significance at the $1 \%, 5 \%$ and $10 \%$ level, respectively.

Panel A. Reduced Form Regressions

\begin{tabular}{|c|c|c|c|c|c|c|}
\hline \multirow[t]{2}{*}{ Dependent Variable: } & \multicolumn{3}{|c|}{ Leverage $=$ Bank Debt $/$ Assets } & \multicolumn{3}{|c|}{ Cash / Assets } \\
\hline & $(1)$ & $(2)$ & (3) & $(4)$ & $(5)$ & $(6)$ \\
\hline Ln(Sales) * Post 2011 & $\begin{array}{c}0.004 * \\
(0.002)\end{array}$ & $\begin{array}{c}0.001 \\
(0.003)\end{array}$ & $\begin{array}{c}0.001 \\
(0.003)\end{array}$ & $\begin{array}{c}-0.003^{* *} \\
(0.002)\end{array}$ & $\begin{array}{c}-0.003 \\
(0.002)\end{array}$ & $\begin{array}{c}-0.003 \\
(0.002)\end{array}$ \\
\hline Above Cutoff * Post 2011 & $\begin{array}{c}0.006 \\
(0.005)\end{array}$ & $\begin{array}{c}0.002 \\
(0.005)\end{array}$ & $\begin{array}{c}0.002 \\
(0.005)\end{array}$ & $\begin{array}{c}-0.001 \\
(0.003)\end{array}$ & $\begin{array}{c}0.003 \\
(0.003)\end{array}$ & $\begin{array}{c}0.003 \\
(0.003)\end{array}$ \\
\hline High TC Access * Post 2011 & $\begin{array}{c}0.003 \\
(0.005)\end{array}$ & $\begin{array}{c}0.004 \\
(0.006)\end{array}$ & $\begin{array}{c}-0.002 \\
(0.007)\end{array}$ & $\begin{array}{c}0.002 \\
(0.003)\end{array}$ & $\begin{array}{c}0.001 \\
(0.003)\end{array}$ & $\begin{array}{c}-0.003 \\
(0.004)\end{array}$ \\
\hline High TC Access * Ln(Sales) * Post 2011 & $\begin{array}{c}0.001 \\
(0.004)\end{array}$ & $\begin{array}{c}0.002 \\
(0.004)\end{array}$ & $\begin{array}{c}0.002 \\
(0.004)\end{array}$ & $\begin{array}{c}0.004 \\
(0.002)\end{array}$ & $\begin{array}{c}0.003 \\
(0.003)\end{array}$ & $\begin{array}{c}0.003 \\
(0.003)\end{array}$ \\
\hline High TC Access * Above Cutoff * Post 2011 & $\begin{array}{c}0.000 \\
(0.008)\end{array}$ & $\begin{array}{c}0.001 \\
(0.008)\end{array}$ & $\begin{array}{c}0.001 \\
(0.008)\end{array}$ & $\begin{array}{c}0.003 \\
(0.004)\end{array}$ & $\begin{array}{c}0.001 \\
(0.005)\end{array}$ & $\begin{array}{c}0.001 \\
(0.005)\end{array}$ \\
\hline (a) Ln(Sales) * Above Cutoff * Post 2011 & $\begin{array}{c}-0.012 * * * \\
(0.003)\end{array}$ & $\begin{array}{c}-0.008^{* *} \\
(0.004)\end{array}$ & $\begin{array}{c}-0.008 * * \\
(0.004)\end{array}$ & $\begin{array}{c}0.007^{* * *} \\
(0.002)\end{array}$ & $\begin{array}{c}0.005 * * \\
(0.002)\end{array}$ & $\begin{array}{c}0.005^{* *} \\
(0.002)\end{array}$ \\
\hline (b) High TC Access * Ln(Sales) * Above Cutoff * Post 2011 & $\begin{array}{c}0.000 \\
(0.006)\end{array}$ & $\begin{array}{c}-0.004 \\
(0.006)\end{array}$ & $\begin{array}{c}-0.004 \\
(0.006)\end{array}$ & $\begin{array}{c}-0.008^{* *} \\
(0.003)\end{array}$ & $\begin{array}{c}-0.006^{*} \\
(0.004)\end{array}$ & $\begin{array}{c}-0.006 * \\
(0.004)\end{array}$ \\
\hline Year FE & Yes & Yes & Yes & Yes & Yes & Yes \\
\hline Firm FE & Yes & Yes & Yes & Yes & Yes & Yes \\
\hline Firm Controls & No & Yes & Yes & No & Yes & Yes \\
\hline Industry $\times$ Year FE & No & No & Yes & No & No & Yes \\
\hline Observations & 52,287 & 45,245 & 45,245 & 52,287 & 45,245 & 45,245 \\
\hline R2 (within Firm FE) & 0.005 & 0.021 & 0.022 & 0.002 & 0.008 & 0.010 \\
\hline
\end{tabular}


Panel B. F-test for Total Effect on Firms in Industries with High TC Access

\begin{tabular}{|c|c|c|c|c|c|c|}
\hline & \multicolumn{6}{|c|}{ F-test for Ho: $(a)+(b)=0$} \\
\hline & $(1)$ & $(2)$ & (3) & $(4)$ & $(5)$ & $(6)$ \\
\hline Sum of coefficients: (a) + (b) & -0.012 & -0.012 & -0.012 & -0.001 & -0.001 & -0.001 \\
\hline F-statistic & 5.41 & 5.82 & 5.57 & 0.23 & 0.14 & 0.11 \\
\hline Prob $>$ F & 0.020 & 0.016 & 0.018 & 0.631 & 0.708 & 0.746 \\
\hline
\end{tabular}




\section{Table 7. Differential Effect on Industries with High TC Access: Trade Credit}

This table reports reduced form regressions for accounts payable (columns 1 to 3 ) and accounts receivable (columns 4 to 6), exploring the differential effect of the shock (based on the triple interaction term: "Ln(Sales) * Above Cutoff * Post 2011") on firms in industries with positive net trade credit borrowing days (i.e. firms with High TC Access). Positive net trade credit borrowing days are calculated at the ISIC 3-digit level using Compustat data between 1990 and 2006. Panel A reports the reduced form regressions. Panel B reports an F-test evaluating whether the added effect of coefficients (a) + (b) is different from zero for each column. All regressions include time and firm fixed effects, columns 2 and 5 add firm controls, and columns 3 and 6 add Industry $\times$ Year fixed effects. Standard errors clustered by firm (in parentheses). ***, **, and $*$ indicates significance at the $1 \%, 5 \%$ and $10 \%$ level, respectively.

Panel A. Reduced Form Regressions

\begin{tabular}{|c|c|c|c|c|c|c|}
\hline \multirow[t]{2}{*}{ Dependent Variable: } & \multicolumn{3}{|c|}{ Accounts Payable / Assets } & \multicolumn{3}{|c|}{ Accounts Receivable / Assets } \\
\hline & $(1)$ & $(2)$ & $(3)$ & $(4)$ & (5) & $(6)$ \\
\hline Ln(Sales) * Post 2011 & $\begin{array}{c}-0.001 \\
(0.002)\end{array}$ & $\begin{array}{c}0.003 \\
(0.002)\end{array}$ & $\begin{array}{c}0.003 \\
(0.002)\end{array}$ & $\begin{array}{l}-0.004^{*} \\
(0.002)\end{array}$ & $\begin{array}{c}-0.001 \\
(0.003)\end{array}$ & $\begin{array}{c}-0.001 \\
(0.003)\end{array}$ \\
\hline Above Cutoff * Post 2011 & $\begin{array}{l}-0.001 \\
(0.003)\end{array}$ & $\begin{array}{c}-0.001 \\
(0.003)\end{array}$ & $\begin{array}{c}-0.001 \\
(0.003)\end{array}$ & $\begin{array}{c}0.001 \\
(0.005)\end{array}$ & $\begin{array}{l}-0.001 \\
(0.005)\end{array}$ & $\begin{array}{c}-0.001 \\
(0.005)\end{array}$ \\
\hline High TC Access * Post 2011 & $\begin{array}{c}-0.014 * * * \\
(0.004)\end{array}$ & $\begin{array}{c}-0.017 * * * \\
(0.005)\end{array}$ & $\begin{array}{c}-0.008 \\
(0.006)\end{array}$ & $\begin{array}{c}-0.003 \\
(0.005)\end{array}$ & $\begin{array}{c}-0.004 \\
(0.005)\end{array}$ & $\begin{array}{c}0.007 \\
(0.006)\end{array}$ \\
\hline High TC Access * Ln(Sales) * Post 2011 & $\begin{array}{c}-0.006 * \\
(0.003)\end{array}$ & $\begin{array}{c}-0.010^{* * *} \\
(0.004)\end{array}$ & $\begin{array}{c}-0.010^{* * *} \\
(0.004)\end{array}$ & $\begin{array}{c}0.001 \\
(0.004)\end{array}$ & $\begin{array}{c}0.000 \\
(0.004)\end{array}$ & $\begin{array}{c}-0.001 \\
(0.004)\end{array}$ \\
\hline High TC Access * Above Cutoff * Post 2011 & $\begin{array}{c}0.000 \\
(0.006)\end{array}$ & $\begin{array}{c}0.005 \\
(0.007)\end{array}$ & $\begin{array}{c}0.004 \\
(0.007)\end{array}$ & $\begin{array}{c}-0.005 \\
(0.007)\end{array}$ & $\begin{array}{c}0.000 \\
(0.007)\end{array}$ & $\begin{array}{c}0.001 \\
(0.007)\end{array}$ \\
\hline (a) Ln(Sales) * Above Cutoff * Post 2011 & $\begin{array}{c}0.005 * * \\
(0.002)\end{array}$ & $\begin{array}{c}0.000 \\
(0.002)\end{array}$ & $\begin{array}{c}0.000 \\
(0.002)\end{array}$ & $\begin{array}{c}0.008^{* * *} \\
(0.003)\end{array}$ & $\begin{array}{c}0.005 \\
(0.003)\end{array}$ & $\begin{array}{c}0.005 \\
(0.003)\end{array}$ \\
\hline (b) High TC Access * Ln(Sales) * Above Cutoff * Post 2011 & $\begin{array}{c}0.012 * * * \\
(0.005)\end{array}$ & $\begin{array}{c}0.017 * * * \\
(0.005)\end{array}$ & $\begin{array}{c}0.017 * * * \\
(0.005)\end{array}$ & $\begin{array}{c}0.000 \\
(0.005)\end{array}$ & $\begin{array}{c}0.000 \\
(0.005)\end{array}$ & $\begin{array}{c}0.001 \\
(0.005)\end{array}$ \\
\hline Year FE & Yes & Yes & Yes & Yes & Yes & Yes \\
\hline Firm FE & Yes & Yes & Yes & Yes & Yes & Yes \\
\hline Firm Controls & No & Yes & Yes & No & Yes & Yes \\
\hline Industry $\times$ Year FE & No & No & Yes & No & No & Yes \\
\hline Observations & 52,287 & 45,245 & 45,245 & 52,287 & 45,245 & 45,245 \\
\hline R2 (within Firm FE) & 0.017 & 0.021 & 0.025 & 0.015 & 0.026 & 0.032 \\
\hline
\end{tabular}


Panel B. F-test for Total Effect on Firms in Industries with High TC Access

\begin{tabular}{|c|c|c|c|c|c|c|}
\hline & \multicolumn{6}{|c|}{ F-test for Ho: $(a)+(b)=0$} \\
\hline & (1) & (2) & (3) & (4) & (5) & (6) \\
\hline Sum of coefficients: (a) + (b) & 0.017 & 0.017 & 0.017 & 0.008 & 0.005 & 0.006 \\
\hline F-statistic & 17.75 & 14.51 & 13.94 & 5.95 & 2.94 & 2.72 \\
\hline Prob $>$ F & 0.000 & 0.000 & 0.000 & 0.015 & 0.087 & 0.099 \\
\hline
\end{tabular}




\section{Table 8. Differential Effect on Industries with High TC Access: Investment and Profitability}

This table reports reduced form regressions for capex (columns 1 to 3 ) and accounts receivable (columns 4 to 6 ), exploring the differential effect of the shock (based on the triple interaction term: “Ln(Sales) * Above Cutoff * Post 2011”) on firms in industries with positive net trade credit borrowing days (i.e. firms with High TC Access). Positive net trade credit borrowing days are calculated at the ISIC 3-digit level using Compustat data between 1990 and 2006. Panel A reports the reduced form regressions. Panel B reports an F-test evaluating whether the added effect of coefficients (a) + (b) is different from zero for each column. All regressions include time and firm fixed effects, columns 2 and 5 include firm controls, and columns 3 and 6 add Industry $\times$ Year fixed effects. Standard errors clustered by firm (in parentheses). ***, **, and * indicates significance at the $1 \%, 5 \%$ and $10 \%$ level, respectively.

Panel A. Reduced Form Regressions

\begin{tabular}{|c|c|c|c|c|c|c|}
\hline \multirow[t]{2}{*}{ Dependent Variable: } & \multicolumn{3}{|c|}{ Capex / Assetst-1 } & \multicolumn{3}{|c|}{ Profit Margin } \\
\hline & $(1)$ & $(2)$ & (3) & $(4)$ & (5) & $(6)$ \\
\hline \multirow[t]{2}{*}{ Ln(Sales) * Post 2011} & -0.001 & 0.001 & 0.000 & $-0.003^{*}$ & -0.002 & -0.002 \\
\hline & $(0.002)$ & $(0.002)$ & $(0.002)$ & $(0.002)$ & $(0.002)$ & $(0.002)$ \\
\hline \multirow[t]{2}{*}{ Above Cutoff * Post 2011} & 0.005 & $0.008 * *$ & $0.006 *$ & -0.001 & 0.001 & -0.001 \\
\hline & $(0.003)$ & $(0.004)$ & $(0.004)$ & $(0.004)$ & $(0.004)$ & $(0.004)$ \\
\hline \multirow[t]{2}{*}{ High TC Access * Post 2011} & 0.003 & 0.005 & $-0.008 *$ & 0.004 & 0.003 & 0.003 \\
\hline & $(0.003)$ & $(0.004)$ & $(0.004)$ & $(0.003)$ & $(0.004)$ & $(0.004)$ \\
\hline \multirow[t]{2}{*}{ High TC Access * Ln(Sales) * Post 2011} & -0.003 & -0.002 & -0.001 & 0.002 & 0.001 & 0.000 \\
\hline & $(0.003)$ & $(0.003)$ & $(0.003)$ & $(0.003)$ & $(0.003)$ & $(0.003)$ \\
\hline \multirow[t]{2}{*}{ High TC Access * Above Cutoff * Post 2011} & 0.001 & -0.002 & 0.000 & 0.002 & 0.000 & 0.002 \\
\hline & $(0.005)$ & $(0.005)$ & $(0.005)$ & $(0.005)$ & $(0.005)$ & $(0.005)$ \\
\hline \multirow{2}{*}{ (a) Ln(Sales) * Above Cutoff * Post 2011} & $-0.006^{* *}$ & $-0.008 * * *$ & $-0.006^{* *}$ & 0.002 & -0.001 & 0.001 \\
\hline & $(0.003)$ & $(0.003)$ & $(0.003)$ & $(0.003)$ & $(0.003)$ & $(0.003)$ \\
\hline \multirow[t]{2}{*}{ (b) High TC Access * Ln(Sales) * Above Cutoff * Post 2011} & $0.008 * *$ & $0.007^{*}$ & 0.005 & -0.003 & -0.001 & -0.003 \\
\hline & $(0.004)$ & $(0.004)$ & $(0.004)$ & $(0.003)$ & $(0.004)$ & $(0.004)$ \\
\hline Year FE & Yes & Yes & Yes & Yes & Yes & Yes \\
\hline Firm FE & Yes & Yes & Yes & Yes & Yes & Yes \\
\hline Firm Controls & No & Yes & Yes & No & Yes & Yes \\
\hline Industry $\times$ Year FE & No & No & Yes & No & No & Yes \\
\hline Observations & 49,208 & 45,245 & 45,245 & 52,287 & 45,245 & 45,245 \\
\hline R2 (within Firm FE) & 0.012 & 0.088 & 0.096 & 0.003 & 0.006 & 0.011 \\
\hline
\end{tabular}


Panel B. F-test for Total Effect on Firms in Industries with High TC Access

\begin{tabular}{|c|c|c|c|c|c|c|}
\hline & \multicolumn{6}{|c|}{ F-test for Ho: $(a)+(b)=0$} \\
\hline & $(1)$ & $(2)$ & (3) & $(4)$ & $(5)$ & (6) \\
\hline Sum of coefficients: (a) + (b) & 0.002 & -0.001 & -0.001 & -0.001 & -0.002 & -0.002 \\
\hline F-statistic & 0.34 & 0.39 & 0.13 & 0.67 & 0.6 & 0.53 \\
\hline Prob $>$ F & 0.558 & 0.534 & 0.720 & 0.412 & 0.441 & 0.466 \\
\hline
\end{tabular}




\section{Table 9. Effect of 2011 Law Change on the Cost of Trade Credit}

\section{Panel A. Baseline}

This table reports reduced form regressions for Costs of Goods / Sales. Reduced form regressions (columns 1 to 3 ) show the effect of a shock to the cost of short-term liquidity loans based on the triple interaction term: "Ln(Sales) * Above Cutoff * Post 2011". All regressions include time and firm fixed effects, column 2 includes firm controls, and column 3 adds Industry $\times$ Year fixed effects. Standard errors clustered by firm (in parentheses). ${ }^{* *},{ }^{* *}$, and * indicates significance at the $1 \%, 5 \%$ and $10 \%$ level, respectively.

\begin{tabular}{lccc}
\hline Dependent Variable: & \multicolumn{3}{c}{ COGS / Sales } \\
\cline { 2 - 4 } & $(1)$ & $(2)$ & $(3)$ \\
\hline & & & 0.001 \\
Ln(Sales) * Post 2011 & -0.002 & 0.000 & $(0.002)$ \\
Above Cutoff * Post 2011 & $(0.002)$ & $(0.002)$ & $-0.008^{* *}$ \\
& $-0.006^{*}$ & $-0.009 * * *$ & $(0.003)$ \\
Ln(Sales) * Above Cutoff * Post 2011 & $(0.003)$ & $(0.003)$ & 0.000 \\
& $0.005^{* *}$ & 0.003 & $(0.002)$ \\
Year FE & $(0.002)$ & $(0.002)$ & Yes \\
Firm FE & Yes & Yes & Yes \\
Firm Controls & Yes & Yes & Yes \\
Industry $\times$ Year FE & No & No & Yes \\
\hline Observations & No & 55,962 & 55,962 \\
$\mathrm{r}^{2}$ (within Firm FE) & 64,564 & 0.007 & 0.020 \\
\hline
\end{tabular}


Panel B. Differential Effect by TC Access

This table reports reduced form regressions for Costs of Goods / Sales, exploring the differential effect of the shock (based on the triple interaction term: "Ln(Sales) * Above Cutoff * Post 2011") on firms in industries with positive net trade credit borrowing days (i.e. firms with High TC Access). Positive net trade credit borrowing days are calculated at the ISIC 3-digit level using Compustat data between 1990 and 2006. Panel C reports an F-test evaluating whether the added effect of coefficients (a) + (b) is different from zero for each column. All regressions include time and firm fixed effects, column 2 includes firm controls, and column 3 adds Industry $\times$ Year fixed effects. Standard errors clustered by firm (in parentheses). ${ }^{* * *}, * *$, and $*$ indicates significance at the $1 \%, 5 \%$ and $10 \%$ level, respectively.

\begin{tabular}{lcccc}
\hline Dependent Variable: & \multicolumn{3}{c}{ COGS / Sales } \\
& $(1)$ & $(2)$ & $(3)$ \\
\hline & & & \\
Ln(Sales) * Post 2011 & $-0.005^{*}$ & -0.002 & -0.002 \\
& $(0.003)$ & $(0.003)$ & $(0.003)$ \\
Above Cutoff * Post 2011 & -0.007 & $-0.013^{* *}$ & $-0.010^{* *}$ \\
& $(0.005)$ & $(0.005)$ & $(0.005)$ \\
High TC Access * Post 2011 & -0.005 & -0.007 & -0.006 \\
& $(0.005)$ & $(0.005)$ & $(0.005)$ \\
High TC Access * Ln(Sales) * Post 2011 & $0.006^{*}$ & 0.006 & 0.006 \\
& $(0.004)$ & $(0.004)$ & $(0.004)$ \\
High TC Access * Above Cutoff * Post 2011 & 0.004 & $0.012^{*}$ & 0.010 \\
& $(0.006)$ & $(0.007)$ & $(0.007)$ \\
(a) Ln(Sales) * Above Cutoff * Post 2011 & $0.008^{* *}$ & $0.007 *$ & 0.004 \\
& $(0.004)$ & $(0.004)$ & $(0.004)$ \\
(b) High TC Access * Ln(Sales) * Above Cutoff * Post 2011 & -0.007 & $-0.008^{*}$ & -0.006 \\
& $(0.005)$ & $(0.005)$ & $(0.005)$ \\
Year FE & Yes & Yes & Yes \\
Firm FE & Yes & Yes & Yes \\
Firm Controls & No & Yes & Yes \\
Industry $\times$ Year FE & No & No & Yes \\
\hline Observations & 51,832 & 44,875 & 44,875 \\
R2 (within Firm FE) & 0.002 & 0.008 & 0.022 \\
\hline
\end{tabular}

Panel C. F-test for Total Effect on Firms in Industries with High TC Access

\begin{tabular}{lccc}
\hline & \multicolumn{3}{c}{ F-test for Ho: (a) $+(\mathrm{b})=0$} \\
\cline { 2 - 4 } & $(1)$ & $(2)$ & $(3)$ \\
\hline Sum of coefficients: (a) + (b) & 0.001 & -0.001 & -0.002 \\
F-statistic & 0.16 & 0.27 & 0.29 \\
Prob $>$ F & 0.692 & 0.601 & 0.591 \\
\hline
\end{tabular}




\section{Internet Appendix}

\section{Table IA.1. Summary Statistics by Below vs. Above Sales Cutoff and Negative vs. Positive Net TC Days}

This table reports summary statistics (means and standard deviation) for our sample of firms during the period 2008-2013. The data source stems from Colombia's Corporations Superintendence (Superintendencia de Sociedades). Summary statistics are divided by firms below and above the sales cutoff of COP 15,000 million (approximately \$5 milllion) and for firms in industries with negative and positive net trade credit borrowing days.

\begin{tabular}{|c|c|c|c|c|c|c|c|c|}
\hline & \multicolumn{4}{|c|}{ Firms Below Sales Cutoff } & \multicolumn{4}{|c|}{ Firms Above Sales Cutoff } \\
\hline & \multicolumn{2}{|c|}{$\begin{array}{l}\text { Negative Net TC } \\
\text { Days Industries }\end{array}$} & \multicolumn{2}{|c|}{ High TC Access } & \multicolumn{2}{|c|}{$\begin{array}{c}\text { Negative Net TC } \\
\text { Days Industries }\end{array}$} & \multicolumn{2}{|c|}{$\begin{array}{l}\text { Positive Net TC } \\
\text { Days Industries }\end{array}$} \\
\hline & Mean & Std. Dev. & Mean & Std. Dev. & Mean & Std. Dev. & Mean & Std. Dev. \\
\hline Bank Debt / Assets & 0.143 & 0.153 & 0.155 & 0.158 & 0.182 & 0.174 & 0.214 & 0.186 \\
\hline ST Bank Debt (1 year or less) / Assets & 0.083 & 0.111 & 0.103 & 0.127 & 0.116 & 0.138 & 0.151 & 0.162 \\
\hline LT Bank Debt (more than 1 year) / Assets & 0.060 & 0.111 & 0.052 & 0.105 & 0.066 & 0.110 & 0.063 & 0.112 \\
\hline Accounts Payable / Assets & 0.094 & 0.116 & 0.194 & 0.174 & 0.099 & 0.110 & 0.218 & 0.174 \\
\hline Accounts Receivable / Assets & 0.209 & 0.178 & 0.245 & 0.189 & 0.217 & 0.170 & 0.267 & 0.188 \\
\hline Cash Holdings / Assets & 0.074 & 0.106 & 0.078 & 0.098 & 0.059 & 0.085 & 0.058 & 0.074 \\
\hline ST Debt Issuance (0 to 60 days) / Assets & 0.016 & 0.054 & 0.014 & 0.046 & 0.043 & 0.101 & 0.034 & 0.081 \\
\hline Capex / Assets & 0.045 & 0.088 & 0.033 & 0.074 & 0.048 & 0.084 & 0.035 & 0.066 \\
\hline Profit Margin & 0.046 & 0.111 & 0.032 & 0.066 & 0.042 & 0.100 & 0.021 & 0.063 \\
\hline Asset Tangibility & 0.186 & 0.178 & 0.147 & 0.161 & 0.167 & 0.146 & 0.131 & 0.137 \\
\hline Asset Turnover & 1.400 & 1.071 & 1.812 & 1.214 & 1.720 & 1.543 & 2.419 & 1.745 \\
\hline Ln(Assets) & 15.419 & 0.933 & 15.088 & 0.757 & 17.504 & 1.318 & 16.909 & 1.193 \\
\hline Asset Growth & 0.168 & 0.343 & 0.143 & 0.286 & 0.168 & 0.326 & 0.157 & 0.280 \\
\hline Age & 19.426 & 11.899 & 18.389 & 11.080 & 26.558 & 16.460 & 20.726 & 13.497 \\
\hline Number of Firm-Years & \multicolumn{2}{|c|}{23,479} & \multicolumn{2}{|c|}{14,937} & \multicolumn{2}{|c|}{9,523} & \multicolumn{2}{|c|}{5,837} \\
\hline Number of Distinct Firms & \multicolumn{2}{|c|}{4,546} & \multicolumn{2}{|c|}{2,840} & \multicolumn{2}{|c|}{1,687} & \multicolumn{2}{|c|}{1,037} \\
\hline
\end{tabular}




\section{Table IA.2. Sample description: Number of firms and observations by industry}

This table reports the number of distinct firms and the number of observations by industry at the ISIC section level.

\begin{tabular}{lcc}
\hline ISIC Section & Number of & Number of \\
& Observations & Firms \\
\hline A - Agriculture, hunting and forestry & 3,856 & 722 \\
B - Fishing & 99 & 19 \\
C - Mining and quarrying & 1,335 & 257 \\
D - Manufacturing & 16,899 & 3,070 \\
F - Construction & 6,503 & 1,330 \\
G - Wholesale and retail trade & 25,269 & 4,703 \\
H - Hotels and restaurants & 1,329 & 252 \\
I - Transport, storage and communications & 2,287 & 443 \\
K - Real estate, renting and business activities & 7,759 & 1,498 \\
M - Education & 380 & 71 \\
N - Health and social work & 149 & 32 \\
O - Other community, social and personal service activities & 1,300 & 243 \\
P - Activities of private households as employers of domestic staff & 47 & 9 \\
Total & & 12,649 \\
\hline
\end{tabular}




\section{Table IA.3. Effect of 2011 Law Change on the Issuance of Short Term Debt for Different Maturities}

This table reports panel regressions of the issuance of short term debt for different maturities, on the triple interaction between firm (log) sales, an indicator equal to one for firms above the cutoff before the tax change (reflecting the increased slope above the cutoff), and a set of indicator variables equal to one for each year between 2008 and 2013, reflecting the slope's flattening year-by-year. All regressions include time and firm fixed effects, firm controls and Industry $\times$ Year fixed effects. Standard errors clustered by firm are reported in parentheses. ***, **, and $*$ indicates significance at the $1 \%, 5 \%$ and $10 \%$ level, respectively.

\begin{tabular}{|c|c|c|c|c|c|}
\hline & \multicolumn{5}{|c|}{ Issuance of ST Debt by Maturity } \\
\hline & 0 to 30 days & 31 to 60 days & 61 to 90 days & 91 to 189 days & 181 days to 1 year \\
\hline \multirow[t]{2}{*}{ Ln(Sales) * Post 2011} & $-0.001^{* *}$ & $-0.001 * * *$ & $-0.001^{*}$ & $-0.005^{* * *}$ & $0.005^{*}$ \\
\hline & $(0.001)$ & $(0.000)$ & $(0.001)$ & $(0.001)$ & $(0.003)$ \\
\hline \multirow[t]{2}{*}{ Above Cutoff * Post 2011} & -0.002 & -0.001 & $-0.008 * * *$ & $-0.007^{*}$ & $0.035^{* * *}$ \\
\hline & $(0.002)$ & $(0.001)$ & $(0.002)$ & $(0.004)$ & $(0.006)$ \\
\hline \multirow[t]{2}{*}{ Ln(Sales) $*$ Above Cutoff * Post 2011} & $-0.006 * * *$ & $-0.005^{* * *}$ & -0.001 & 0.000 & -0.002 \\
\hline & $(0.001)$ & $(0.001)$ & $(0.001)$ & $(0.003)$ & $(0.004)$ \\
\hline Year FE & Yes & Yes & Yes & Yes & Yes \\
\hline Firm FE & Yes & Yes & Yes & Yes & Yes \\
\hline Firm Controls & Yes & Yes & Yes & Yes & Yes \\
\hline Industry $\times$ Year FE & Yes & Yes & Yes & Yes & Yes \\
\hline Observations & 56,535 & 56,535 & 56,535 & 56,535 & 56,535 \\
\hline$r^{2}$ (within Firm FE) & 0.024 & 0.021 & 0.016 & 0.011 & 0.018 \\
\hline
\end{tabular}


Table IA.4. Robustness Test on the Effect of 2011 Law Change on the Issuance of Short Term Debt (0 to 60 days): Allowing Coefficient on Ln(Sales) * Above Cutoff to vary by Year

This table reports panel regressions of the issuance of short term debt (maturities between 0 and 60 days) on the triple interaction between firm (log) sales, an indicator equal to one for firms above the cutoff before the tax change (reflecting the increased slope above the cutoff), and a set of indicator variables equal to one for each year between 2008 and 2013, reflecting the slope's flattening year-by-year. All regressions include time and firm fixed effects, column 2 includes firm controls, and column 3 adds Industry $\times$ Year fixed effects. Standard errors clustered by firm are reported in parentheses. ${ }^{* * *}$, **, and $*$ indicates significance at the $1 \%, 5 \%$ and $10 \%$ level, respectively.

\begin{tabular}{|c|c|c|c|}
\hline & \multicolumn{3}{|c|}{ Issuance of ST Debt (0 to 60 days) } \\
\hline & (1) & $(2)$ & (3) \\
\hline Ln(Sales) * Above Cutoff & $\begin{array}{l}-0.001 * \\
(0.001)\end{array}$ & $\begin{array}{c}-0.002 * * * \\
(0.001)\end{array}$ & $\begin{array}{c}-0.002 * * * \\
(0.001)\end{array}$ \\
\hline Above Cutoff * Post 2011 & $\begin{array}{c}-0.006^{* *} \\
(0.002)\end{array}$ & $\begin{array}{c}-0.006^{* *} \\
(0.003)\end{array}$ & $\begin{array}{c}-0.005^{* *} \\
(0.003)\end{array}$ \\
\hline Ln(Sales) $*$ Above Cutoff $*[$ Year $=2008]$ & $\begin{array}{c}0.007^{* * *} \\
(0.001)\end{array}$ & $\begin{array}{c}0.002 \\
(0.002)\end{array}$ & $\begin{array}{c}0.002 \\
(0.002)\end{array}$ \\
\hline Ln(Sales) $*$ Above Cutoff $*[$ Year $=2009]$ & $\begin{array}{c}0.001 \\
(0.001)\end{array}$ & $\begin{array}{l}-0.001 \\
(0.001)\end{array}$ & $\begin{array}{l}-0.001 \\
(0.001)\end{array}$ \\
\hline Ln(Sales) $*$ Above Cutoff $*[$ Year $=2010]$ & - & - & - \\
\hline Ln(Sales) $*$ Above Cutoff $*[$ Year $=2011]$ & $\begin{array}{c}-0.010^{* * *} \\
(0.002)\end{array}$ & $\begin{array}{c}-0.011^{* * *} \\
(0.002)\end{array}$ & $\begin{array}{c}-0.011^{* * *} \\
(0.002)\end{array}$ \\
\hline Ln(Sales) $*$ Above Cutoff $*[$ Year $=2012]$ & $\begin{array}{c}-0.009 * * * \\
(0.002)\end{array}$ & $\begin{array}{c}-0.013^{* * *} \\
(0.002)\end{array}$ & $\begin{array}{c}-0.013^{* * *} \\
(0.002)\end{array}$ \\
\hline Ln(Sales) $*$ Above Cutoff $*[$ Year $=2013]$ & $\begin{array}{c}-0.011^{* * *} \\
(0.002)\end{array}$ & $\begin{array}{c}-0.012^{* * *} \\
(0.002)\end{array}$ & $\begin{array}{c}-0.012^{* * * *} \\
(0.002)\end{array}$ \\
\hline Year FE & Yes & Yes & Yes \\
\hline Firm FE & Yes & Yes & Yes \\
\hline Firm Controls & No & Yes & Yes \\
\hline Industry $\times$ Year FE & No & No & Yes \\
\hline 0.000 & 61,461 & 56,535 & 56,535 \\
\hline $\mathrm{r}^{2}$ (within Firm FE) & 0.028 & 0.032 & 0.036 \\
\hline
\end{tabular}

